\title{
WHAT IS THE PHONOLOGICAL WORD IN DAGBANI? A POSITIONAL FAITHFULNESS ACCOUNT*
}

\author{
Fusheini Hudu
}

\begin{abstract}
This paper offers a phonological diagnostic for defining the word in Dagbani, a Gur language of Ghana. It shows that a morphological unit that constitutes a complete word blocks contrast-neutralising phonological processes from target segments within its boundaries when triggered across its boundary. In sub-word units, these processes (e.g. nasal place assimilation, vowel harmony, segmental deletion) apply to target sounds without restrictions. The result is the maintenance of contrast in words and neutralisation of contrast in sub-words. The paper further argues that the asymmetrical application of these rules is an indication of a morphological strength distinction between the word as a strong position where segments are fully specified for phonological features, and the sub-word domain as a non-privileged position where segments may be underspecified for features. A formal analysis of the asymmetry is presented using the theory of positional faithfulness within the framework of Optimality Theory.
\end{abstract}

Keywords: Dagbani, nasal place assimilation, vowel harmony, underspecifiation, positional faithfulness

http://dx.doi.org/10.4314/gjl.v3i1.1

\section{Introduction}

The goals of this paper are three. First, it reviews previous descriptions of the various morphological units in Dagbani, a Gur language of Ghana. These units have been described at different levels of detail in previous studies (e.g. Olawsky 1999, 2002; Hudu 2005, 2010, 2012). The second goal is to define the phonological word in Dagbani using phonological processes. In doing so, a boundary is drawn between morphological units that are full words and those that are sub-words. The third goal is

\footnotetext{
* Many thanks to the editor-in-chief of the GJL and reviewers for their useful comments. The manuscript for this publication was aided by a fellowship from the African Humanities Program, established by the American Council of Learned Societies with financial support from the Carnegie Corporation of New York.

${ }^{+}$PhD (University of British Columbia). Lecturer, Department of Linguistics, School of Languages, University of Ghana. Research focus: phonetics, phonology, morphology, psycholinguistics, Dagbani.
} 
to demonstrate that the distinction between a full word and a sub-word can be accounted for using the theory of position faithfulness (Beckman 1997, 1998) within the framework of Optimality Theory (Prince and Smolensky 1993/2004). The paper illustrates this with a formal account of nasal place assimilation (NPA), vowel harmony and lateral deletion.

This is not the first study to use phonological processes to define the Dagbani phonological word. Similar previous studies include Olawsky (2002) and others. The analyses show that phonological processes have the tendency to compromise the featural integrity of segments in various constituents. The asymmetrical effect of these processes on various morphological units is useful in defining the differences between these units and ultimately determining their wordhood. The phonological patterns in Dagbani show that a unit that constitutes a phonological word is positionally strong. It blocks phonological processes triggered across its boundary to ensure that phonemic contrasts between segments are fully maximised. Sub-word morphological units, on the other hand, are non-privileged positions which impose less restrictions on the application of phonological processes. Segments within them are targets of phonological processes triggered within or across their boundaries. Thus in arguing for the role of these processes as phonological diagnostics in defining a morphological category, the paper also makes the crucial claim that a successful account of the asymmetries observed here can not be achieved without reference to the morphological units within which segments surface.

The data used in this paper reflect the Eastern and Western dialects of Dagbani. The primary data are based on my intuitions as a native speaker and elicitations and observations from other speakers. All data are presented in phonemic or phonetic transcription, not in the orthography. Tone marking is based solely on the Eastern Dialect, and restricted to high, low and falling tones. The vowels and consonants forming the segmental inventory of Dagbani are shown in (1) and (2), cited from Hudu (2010). Allophones are in square brackets.

(1) Vowel inventory

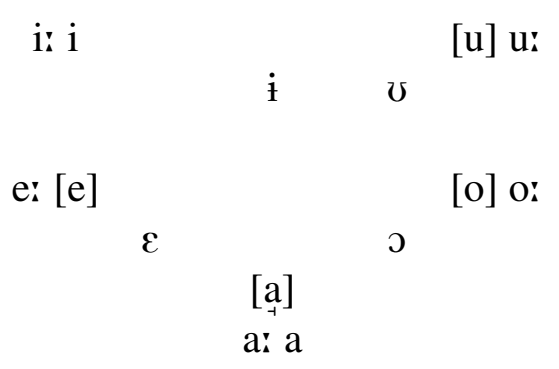


(2) Consonant inventory

\begin{tabular}{|c|c|c|c|c|}
\hline $\mathrm{p}$ & $\mathrm{t}$ & & $k[t]$ & $\hat{\mathrm{kp}}[\mathrm{tp}]$ \\
\hline b & $\mathrm{d}[\mathrm{r}]$ & & $g[\mathrm{~d}]$ & $\mathrm{gb}[\hat{\mathrm{db}}]$ \\
\hline $\mathrm{f}$ & $\mathrm{s}\left[\int\right]$ & & [x] & \\
\hline $\mathrm{V}$ & $\begin{array}{l}\mathrm{z}[3] \\
1\end{array}$ & & & \\
\hline $\mathrm{m}$ & $\mathrm{n}$ & n & $\eta$ & ᄁym $[\mathrm{nm}]$ \\
\hline
\end{tabular}

The rest of this introduction takes a look at the phonological word in a cross linguistic perspective and the notion of positional privilege in phonology. Section 2 describes Dagbani morphology and the various morphological units that are discussed in this paper. The two subsequent sections analyse various phonological processes that serve as diagnostics for defining the phonological wordhood of various morphological constituents. These are nasal place assimilation in Section 3, and vowel harmony and segmental deletion in Section 4. Section 5 demonstrates how a positional faithfulness approach can account for the differences between sub-phonological words and full words, illustrating this with a formal account of these processes. Section 6 presents the summary and conclusions of the paper.

\subsection{Defining the phonological word}

Research on the word as a linguistic unit has hardly succeeded in providing a comprehensive definition that characterises the nature of the word cross-linguistically. What has been relatively successful is a distinction between phonological word and grammatical word as two different cross-linguistic units. Dixon and Aikhenvald (2002:13) define a phonological word as a phonological unit typically larger than the syllable which generally has more than one phonological defining property chosen from the three areas shown in (3).

(3) (a) Segmental features - internal syllabic and segmental structure; phonetic realisations in terms of this; word boundary phenomena; pause phenomena.

(b) Prosodic features - stress (or accent) and/or tone assignment; prosodic features such as nasalisation, retroflexion, vowel harmony.

(c) Phonological rules - some rules apply only within a phonological word; others (external sandhi rules) apply specifically across a phonological word boundary. 
Discussions of the phonological word in Dagbani have touched on each of the three areas noted by Dixon and Aikhenvald. Dakubu (1997) observes that the phonological word in Central Gur, of which Dagbani is part, typically consists of two morphological units: (i) a thematic CV syllable which has a full range of articulatory contrasts and (ii) a mono- or bi-syllabic suffix which has restricted vowels and consonants. She further notes that the vowels of suffixes 'tend to be at least partly determined by the features of the thematic syllable vowel' (Dakubu 1997:83). Olawsky (2002) explores the nature of the Dagbani phonological word using syllable structure, tone, vowel harmony and other phonological processes. Hudu $(2010,2013)$ shows that [ATR] harmony is restricted to the domain of one lexical root. He defines the phonological word as a lexical root accompanied by prefixes, suffixes, proclitics and enclitics.

In this paper, the phonological word is established using one diagnostic: phonological rules triggered across the boundary of the morphological unit to which the target segment belongs. The various phonological processes discussed here are those that trigger the loss of constrast through harmony, phonetic assimilation, featural dissimilation or even deletion. Most of these processes take place when morphemes are concatenated. The observation is that, the application of these processes is conditioned on the mophological category containing the potential target. When the triggering segment or environment and the potential target are not part of the same morpheme, harmony will take place only when the potential target is part of an affix, clitic or bound lexical root. When the morphological environment within which the potential target surfaces is a word, these processes are blocked. The conclusion is that, these processes only apply across sub-word boundaries, they do not apply across the boundaries of full phonological words.

\subsection{Positional privilege and positional faithfulness}

The observation that phonological processes may be constrained by linguistic units has been made in previous research as far back as Troubetzkoy (1939). More recent studies and observations include Casali (1997); Beckman $(1997,1998)$ among others. These studies show that there exists an asymmetry between two domain types. One domain category consists of forms in which various phonological processes that result in the neutralisation of underlying contrast (e.g. lenition, various forms of assimilation, deletion etc) readily take place. The other category includes forms in which such forms of neutralisation are blocked. Lexical roots, root-initial syllables, stressed syllables and syllable onsets are privileged positions, prosodically and psycholinguistically, that often preserve segmental contrasts. Affixes, root-internal syllables, unstressed syllables, and syllable codas are non-privileged positions where contrasts are often lost. 
Also observed as a factor in conditioning phonological processes is lexical category. Compared with other lexical categories, nouns show privileged phonological behaviour in that they license more phonological contrasts and resist processes of neutralisation or deletion. This has been shown in research on many languages such as Spanish (Harris, 1969), Sinhala (Letterman, 1997), Arabic (McCarthy and Prince, 1990, 1995) (see Smith 2001 for extensive review and discussion). Even though it is not the focus of this paper, and no known previous study on Dagbani discusses it, a preliminary observation of nasal place assimilation shows that Dagbani also treats nouns as a more privileged lexical category than verbs. As shown in Section 3, when preceded by an underlyingly placeless nasal proclitic, a vowel-initial noun inserts the syllable da initially to provide a consonant to licence the place specification of the nasal proclitic. A vowel-initial verb in a similar context deletes the initial vowel to produce a consonant-initial surface form that licenses the place specification of the preceding nasal.

The focus of this paper is on the contrast between bound roots, affixes and clitics on one hand and simplex words, complex words and compounds on the other. This contrast also bears similarities with the asymmetries observed in the languages cited. The nonlexical and bound lexical morphemes pattern together as non-privileged positions, the non-bound lexical items behave as privileged positions. Units in the former category are subject to phonological neutralisation resulting from various phonological processes. In the latter positions, these forms of neutralisation are blocked.

One approach within Optimality Theory to analysing the asymmetry has been with the use of positional faithfulness constraints (Beckman 1997, 1998). These are constraints that require output preservation of underlying contrast in privileged linguistic positions. Through appropriate ranking with other constraints, positional faithfulness constraints have the effect of blocking in prominent positions, phonological processes that lead to neutralisation of underlying contrast, thus limiting such neutralisation patterns to non-privileged positions. This paper argues that the various processes can be unified under a positional faithfulness account, illustrating this with analysis of nasal place assimilation.

\section{Dagbani morphology}

Morphologically, Dagbani is an agglutinative language, with some level of fusion caused by morphophonological rules typically affecting nouns and adjectives. The word order is SVO. For the purpose of the discussion in this section, morphological units in the language are categorised into words, affixes and clitics. 


\subsection{Words}

Dagbani words can be categorised into three: simplex, complex and compound words. A simplex word consists of only one lexical root. For verbs, this can be as short as a $\mathrm{CV}$ or CVC root in the infinitive form, which does not require an affix. The simplex verb may also be inflected for aspectual markers (4a-b) or followed by clitics (4c-e). An underlying verb may also take a derivational suffix to produce words of different lexical categories, as in (4f-g). In (4) and all other data, a segment in square brackets is epenthetic. Clitics are not preceded by hyphens, unlike affixes.

(4) Verbs

\begin{tabular}{|c|c|c|c|}
\hline a. tì & 'give' & tì-já & 'give-perf.' \\
\hline wólg[î̀] & 'separate' & wòlg[ì]-rá & 'separate-imperf.' \\
\hline màl[1] & 'make' & màl lí & 'make it' \\
\hline zày & 'take/have' & zày nà & 'take hither (bring)' \\
\hline kpàys[i] & 'encourage' & kpàys ô & 'encourage him/her' \\
\hline 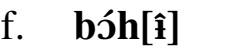 & 'ask' & bòh-gú & 'question-sg.' \\
\hline g. lù & 'fall' & lớ-á & 'fall-sg.' \\
\hline
\end{tabular}

For typical nouns and adjectives, a simplex word consists of a lexical root and a number suffix bound to each other. Unlike the lexical root, there are a limited number of nominal/adjectival suffixes which mark singular and plural number, among other functions, and form the basis for the classification of nouns and adjectives in the language, as discussed further in Section 2.2. The smallest free standing unit for a typical noun or adjective is a lexical root inflected with a singular or plural nominal suffix. However, the underlying phonological featural composition of a nominal/adjectival root appears in complex words, which consist of more than one lexical root inflected with only one number suffix. In a simple singular/plural form, segments in the root may be targets of assimilatory processes triggered by segments in the suffix. They may also undergo phonological processes resulting from the suffixation of the number markers. In complex words, only the final root is followed by a number suffix. All roots preceding the final root are followed by other lexical roots. The data in (5) show the distinction between simplex nouns and adjectives in the singular and plural forms and complex nouns consisting of only two lexical roots.

(5) Structure of Dagbani nouns and adjectives

\begin{tabular}{lllll} 
Singular & Plural & \multicolumn{3}{c}{ noun+adjective/noun+noun } \\
a. bóP-ó & bóP-rí & 'arm' & bò? bíl-á & 'small arm' \\
b. páP-á & páP-bá & 'wife' & pà?-pál-ó & 'new wife' \\
c. dór-ó & dór-tí & 'disease' & dòr kứr-lí & 'old disease' \\
d. jé-é & jé-hí & 'nose' & jè vó-lí & 'nostril'
\end{tabular}



e. má:n-í
mán-â 'okra'
má:y kú:n-í 'dry okra'
f. jíl-î
jí-jâ 'house'
jíl tîtá-lí
'big house'
g. wàh-ơ jùr-î 'horse'
wàr díb-gâ 'stallion'
h. kpán-gá
[kpán:]
kpín-î 'guinea fowl'
kpá:n gbál-i 'guinea fowl leg'

The examples in (5a-b) are cases with roots unchanged in all contexts in their segmental and featural composition. (5c-d) are instances where features of segments in the singular forms of the roots change due to an assimilatory process triggered by the singular nominal suffix while (5e-f) represent instances where the plural root forms are different. Although quite rare, there are cases where both singular and plural root forms differ from the underlying root form shown in the complex word. Examples are shown in $(5 \mathrm{~g}-\mathrm{h})$. The rules governing some of these changes form part of the subject of discussion in the sections to come. In the rest of this paper, any reference to the underlying form of a nominal or adjectival root means the form of the root in a complex word preceding one or more nominal/adjectival roots. The data in (6) show that many nominal/adjectival roots can be stacked into one complex word whose suffix is the suffix of the last nominal or adjectival root.

(6) Building complex nouns
a. nà-á
b. nà-bí-hí
c. nà-bì-pò?ín-gá
d. nà-bì-pò?ín-zé-é
e. nà-bì-pù?ín-zé-vèl-lí
'chief-sg.'
'chief's child-pl. (princes)'
'chief's female child-sg. (princess)'
'fair coloured princess'
'beautiful fair coloured princess'
f. nà-bì-pò?în-zé -vèl-wó?íl-á 'tall beautiful fair coloured princesses'

Compounds differ from complex words in that they combine two simplex words without restrictions on their inflection. The data in (7) illustrate associative construction in Dagbani, a compound construction that combines two nouns, the second noun associated with the first.

\begin{tabular}{|c|c|c|c|c|}
\hline \multicolumn{5}{|c|}{ Possessive Construction } \\
\hline & & possessed & compound & \\
\hline a. & nà-á & bí-hí & nàà bíhí & 'chief's children' \\
\hline b. & náh-ú & zư?-ô & náhư zư?ô & 'cow's head' \\
\hline c. & wób-gû & mà & wóbgú mâ & 'elephant's mother' \\
\hline d. & bá-á & bín-dí & báá bín-dí & 'dog's shit' \\
\hline e. & báP-á & kòl-gú & báPá kól-gư & 'soothsayer's sack' \\
\hline
\end{tabular}


The difference between $(6 b)$ and $(7 a)$ is that, in nàbíhí, nàá is modifying bíhí whereas in nàà bíhí, bíhí is associated with nàá. Thus nàà bíhí is an associative construction surfacing as a compound headed by nàá. The two words in (6b) and (7a) thus differ significantly in their meanings. In nàà bíhí, the children are identified as having some unique association with the chief. There are several pragmatic contexts in which it can be used. It could refer to princes beloved to the chief and used to make a distinction between such princes and other children of the chief. But it could also be used to refer to children who are not the chief's sons or daughters. The children could be the chief's messengers or servants. Similarly, náhú zứv̂ refers to the head of a live cow. The severed head of a dead cow is expressed as a complex word with cow describing head (ná? zú? û 'cow head').

Thus for each of the compounds in (7), there could be a complex construction that differs along a similar line. The compound in (7c) is interesting in the sense that it is ambiguous. One meaning is the compositional meaning stated in (7). Another meaning is semantically non-compositional, and refers to a type of rodent, about the size of a baby rat. Another such example is the word sá-á páp-á which literally means 'rain's wife' but actually means 'dragonfly'. The point of these comparisons is that, while compounds sometimes convey such non-compositional meanings, complex words are compositional in meaning.

In compounding, the last vowel of the first noun of a compound may be reduced to [i] or elided all together due to its location within the compound. When the suffix of this noun does not have an onset, such a deletion may give the impression that the suffix is

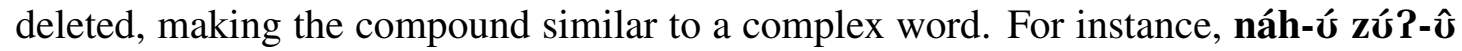
'cow's head' may be pronounced as náh zư? ช̂, and bá?-á kól-gứ 'soothsayer's sack' as bá? kól-gú. This is especially likely in casual speech. However, such a reduction is not phonological, as it does not affect the phonology in any way. With the exception of the vowel elision or reduction, the first root of the compound remains phonologically distinct from that of a complex word in all other ways. Thus náh zú? $\hat{v}$ maintains a root coda distinct from ná? zứ û. bá? kól-gú also maintains the high tone of the root vowel making it different from bà? kòl-gú, a complex word in which 'soothsayer' modifies 'sack'. This is further demonstrated in Section 3.4, where such a vocalic elision may leave a preceding nasal exposed to an oral consonant in the following word. However, in such forms, nasal place assimilation fails to take place, unlike the root-root sequence in complex words, where a nasal at the right edge of the first lexical root assumes the place specification of the initial consonant of the second lexical root. 


\subsection{Affixes and clitics}

The most studied affixes in Dagbani are nominal/adjectival suffixes that mark singular and plural number, as evidenced from the already cited literature. These have been shown in the preceding data. There are three important roles nominal/adjectival number suffixes play, beyond encoding number and making the nouns and adjectives to which they are suffixed complete words. First, the limited set of suffixes form the basis for classifying Dagbani nouns and adjectives, such that all nouns and adjectives that belong to one class take the same singular and plural nominal suffixes. For instance, nouns that take the singular nominal suffix -li also take the plural nominal suffix -a, and thus belong to one class, as observed in previous studies on Dagbani morphology (e.g. Benzing 1971, Wilson 1972, Olawsky 1999, Hudu 2005, Miehe 2012). Previous proposals on the noun class system of Dagbani range from five to seven classes, with some proposing sub-classes. Number suffixes have also been used in determining the noun class systems of related Gur languages such as Mampruli, Frafra, Kasem, Buli, Talni (Naden 1988), and Gur languages in general, following the works of early researchers such as Gabriel Manessy and others from the early 1960s and before. This is discussed extensively in the eidted collections of Gudrun Miehe, Brigitte Reineke and Kerstin Winkelmann (Miehe and Winkelmann 2007 and Miehe et al. 2012).

Second, suffixes sometimes help to disambiguate homophonous roots. The noun pairs in (8), cited from Olawsky (1999), with some changes to transcription and added tone marks, illustrate this point.

(8) Number suffixes disambiguating homophonous roots (Olawsky 1999)
singular plural
a. tٔ́ér-lî̀ tfér-â 'driver ant'
singular plural
b. sál-lí sál-á 'charcoal'
tfér-gá ţér-tí 'ladle'
c. jứ-lî̀
jú-jâ
'name'
sál-gá sál-sí 'weevil'
d. kál-lí kál-á 'segment'
jớâa jó-hî̀ 'flute'
e. kpál-gá kpál-sí 'type of tree'
kál-ó kál-tí 'enamelware'
kpál-gô kpál-t̂̂ 'dawadawa spice’

Third, suffixes play a semantic role in that the choice between two nominal suffixes both marking singularity or plurality for suffixation to the same root may result in slight meaning differences or encode another semantic property such as animacy. Examples are shown in (9). 
(9) Modifying nominal suffixes

\begin{tabular}{|c|c|c|c|}
\hline a. pál-ó & 'new-sg. (anim.)' & pál-lí & 'new-sg. (inanim.)' \\
\hline b. pál-bá & 'new-pl. (anim.)' & pál-á & 'new-pl. (inanim)' \\
\hline kứr-ó & 'old-sg. (anim)' & kứr-lí & 'old-sg. (inanim.)' \\
\hline té-é & 'small piece-sg.' & tீé-?ú & 'broken piece-sg.' \\
\hline bé-é & 'mischievous person-sg.' & bé-Pú & 'bad/ugly one-sg.' \\
\hline 3è-é & 'red-sg.' & 3è-?ú & 'reddish-sg.' \\
\hline g. pèl-lí & 'white-sg.' & pèl-gá & 'sparkling white' \\
\hline h. sábín-lí & 'black-sg.' & sáblí-gá & 'ugly black-sg.' \\
\hline kòr-ê & 'desire' & kòr-ŝ́ & $\begin{array}{l}\text { 'temptations/' } \\
\text { unattained interests' }\end{array}$ \\
\hline
\end{tabular}

The different suffixes in (9a-c), mark distinct animacy, in addition to being number suffixes. The adjective téé describes a noun that, by its nature, exists as a piece. For instance, in ním tféé 'a piece of meat', tfé-é modifies meat of a size that can be consumed without the need to cut it into further pieces. It describes the meat as a part of

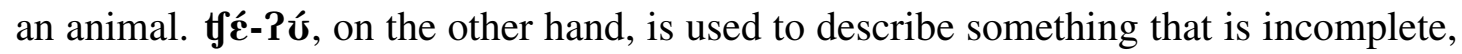
and for which reason, typically less or not useful. For instance, a piece of a broken earthenware of any size is described as la tfé-?ó. In (9e), the suffixes encode different 'objects'. In bé-é, it is solely the character of a person that is encoded, and is used solely to describe humans. bé-?ó is, by default, used to encode the physical appearance of any noun, but can also be extended to encode the character of an animate being. The use of a suffix can also encode a generic/neutral sense of a colour term (e.g. -lì in pèl-líi, sábín-lí), complementation (e.g. -gá in pèl-gá) or perjoration (as in -gá in sáblí-gá).

The limitation is that, compared with the number marking function of the suffixes, the semantic function only seems to apply to a limited set of words. Nevertheless, given these varied roles of the nominal suffixes, it is more accurate to refer to them generally as nominal suffixes and use the terms 'singular nominal suffix' and 'plural nominal suffix' when focusing on their number marking roles, as done in this paper. The term 'number suffix' used in previous research limits their function to number marking. It also fails to recognise that some nouns that take these suffixes (e.g. dż̀lín-sí 'fatigue') clearly do not have two forms marking singular and plural number. While the encoding of singular and plural number is the most widespread use of these suffixes, the need for the suffixes is driven fundamentally by the morphological rule that nominal and adjectival forms take a suffix to make them distinct from verbs.

Dagbani also has suffixes and prefixes surfacing as reduplicants to roots of different lexical categories, as observed in some previous studies (e.g. Hudu 2010, 2013). Verbs take prefixes and suffixes that mark aspect. There are also derivational suffixes and grammaticalised lexical words that surface as prefixes to lexical roots. As 
discussed in the following sections, the differences in the roles of verbal and nominal/adjectival affixes are crucial to understanding the status of nominal/adjectival roots as sub-phonological words.

There are proclitics and enclitics surfacing as pronominal markers, focus markers among others. Like bound roots and affixes, the clitics always require a lexical root to surface. However, they are separate grammatical words, as some of them are full phonological words when they surface in emphatic forms. For this paper, the only clitics that are of interest are the first person singular possessive and the infinitive markers, which surface as nasals. The clitics are discussed further in Section (3).

\section{Nasals in various morphological units}

As the consonant inventory in (2) shows, Dagbani has five contrastive nasals: /m, n, n, $\mathrm{\eta}, \overline{\mathrm{\eta}} \mathrm{m} /$. The labial-dorsal $/ \mathrm{\jmath} \mathrm{m} /$ surfaces as a labial-coronal $[\mathrm{nm}]$ before front vowels, (where $/ \mathrm{kp}, \mathrm{gb} /$ also surface respectively as [tp,$\widehat{\mathrm{db}}$ ] (Ladefoged 1968)). With the exception of $/ \mathrm{ym} /$, for which there are no available data, all nasals undergo assimilation to the place of an immediately following consonant. Depending on the place specification of the following consonant, any of the nasals, including [ $\mathrm{ym}]$, may surface as the output of nasal assimilation. Nasal place assimilation is thus very widespread in Dagbani, as it is in many languages. However, a critical look at the various contexts where nasals assimilate reveals that only nasals located in affixes or serving as clitics and bound roots undergo the process when the trigger and target are located in different morphemes. Nasals that surface in free standing words maintain their underlying place specification when a potential trigger of NPA is located outside of the minimal word that contains the nasal. Each of the subsections below discusses one of these contexts. Because NPA only targets nasals that immediately precede other consonants (NC sequences), the focus is on nasals at the right edge of the various morphological constituents.

\subsection{Affix nasals}

The data in (10) show the cardinal prefix in Dagbani, which is a nasal. It assumes the same place of articulation as the following consonant. 
(10) Effects of NPA on nasal cardinal prefix
a. n-dàim 'one'
e. n-ní: 'eight'
b. n-tá
f. n-jí 'two'
c. n-náhí 'four'
g. n-jóbú 'six'
d. n-nú 'five'
h. y-wói 'nine'

Similarly, a nasal at the right edge of a reduplicant prefix assumes the place specification of the consonant it immediately precedes, (11). The reduplicants are underlined.

(11) NPA in reduplicant prefixes.
a. púm-póyó
'right now'
b. bùm-bòñ:
'extreme darkness'
c. dùn-dòñ
'court yard'
d. zùn-zú-lí
'maggot-sg.'
e. kùn-kôn
'can/tin'

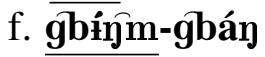
'elephant grass'
g. ŷmíñm-ŷmin-í
'closely kept secrete'

In addition to the reduplicant prefix, Dagbani has a fixed suffix liN syllable in some reduplicants. The nasal in this fixed syllable assumes the place specification of the initial consonant of the following base. This is illustrated in (12).

(12) Fixed -lin syllable in Dagbani reduplication ${ }^{1}$
a. pù-lòm-pùm-gá [pò-lòm-pòñ] 'type of tree'
b. dè-lìn-d
c. sá-lín-sá-hî 'tiny ant-pl.'
d. dí-lín-dí-hî 'numbness'

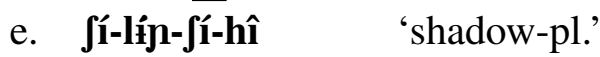
f. ká-lín-ká-?̂u 'crown-sg.'
g. kứ-lớn-kứ-hî 'beetle-like insect-pl.' (Blench 2004)
h. ḱpí-línm-ḱpí-hî 'epilepsy'

Unlike nasal clitics, discussed in Section 3.2, there seem to be no data in which these $\mathrm{N}$ and CVN affixes precede vowel-initial words, which are quite rare in the language. For this reason, it is difficult to determine what the underlying place specification of the nasals may be. Without such evidence, the default conclusion that these nasals are underlyingly unspecified for any place feature holds.

\footnotetext{
${ }^{1}$ See Hudu (2010) for arguments on why the data in (12) constitute a suffixing reduplication with lìN as a suffix to the preceding syllable and not a prefix to the following syllable.
} 


\subsection{Clitic nasals}

A nasal proclitic (1st person singular, 1st person singular possessive, infinitive) always assumes the place specification of the following consonant. The data in (13) show this.

(13) Effects of NPA on nasal proclitics

1 st person singular possessive

a. J f́r-gá 'my needle'

Infinitive particle

b. y yó-?ú 'my fox'

g. jn fè 'sew'

c. y wò-hư 'my horse'

h. y yòbì 'chew'

d. n sám-lî̀ 'my debt'

i. y wòhì 'teach'

e. m bâ 'my father'

j. n sâm 'to mash'

f. m vó-?̂̂ 'my leaf'

k. m bá 'to ride'

1. m vớhí 'to rest'

Given that Dagbani lexical words typically begin with consonants, the pattern in these words is what is typically found in the language. However, there are vowel-initial lexical words, typically loans, which may also be preceded by nasal clitics. In such cases, two strategies are adopted to provide a consonant to license the place specification of the nasal. The first is the insertion of a CV syllable da into the lexical word whose onset provides a place to trigger assimilation of the nasal clitic, (14).

(14) NPA in vowel-initial nouns: da insertion.
a. /N ànfò:ní/ [n dàànfò:ní] 'my picture' (Akan)
b. /N àlàhzíbá/ [n dààlàhzíbá] 'my wonders' (Arabic via Hausa)
c. /N àlìzífứ/ [n dààlìíf́úu ] 'my pocket'
d. /N àlìzàmá/ [n dààlìzàmá] 'my conversation'
e. /N ámáni/ [n dààmání] 'my cooking fish'
f. /N ànfa:ni/ [n dàànfà:ní] 'my grace' (Hausa)
g. /N àlìzíni/ [n dààlìzíní] 'my genie' (Arabic)

The second strategy is to delete the initial vowel of the lexical word to make way for the following consonant to license the place specification of the nasal, as shown in (15). All loans in (15) are from English. ${ }^{2}$

(15) NPA in vowel-initial verbs: vowel deletion.

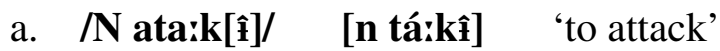
b. /N ana:ns[î̀]/ [n ná:nsî́] 'to announce'

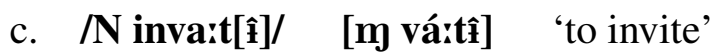

\footnotetext{
${ }^{2}$ The view that these words, especially $(15 \mathrm{~b}, \mathrm{c})$, are loans is a bit contentious. While their use is quite widespread among peakers who do not understand English, it is not obvious that they are simply not trying to demonstrate that they have some knowledge of English. In the case of speakers who understand English, (15a) often surfaces as a codemixed word in sentences.
} 
It is not obvious why a syllable (rather than a consonant) is inserted in (14), and where the syllable comes from. The epenthesised -da does not seem to be related to any known morpheme in the language. However, the differences between the data in (14) and those in (15) is quite obvious. In (14), the words are nouns and adjectives, whereas in (15), they are verbs. While vowel deletion and da insertion are two opposing strategies, they have the same goal of ensuring that the lexical word has a consonant at its left edge to license the place of articulation of the nasal clitic. This provides an indication that the $\mathrm{N}$ proclitic in Dagbani is underlyingly placeless. If the proclitic had an underlying place of articulation, that underlying place specification would have surfaced when preceding a vowel-initial lexical word. The difference in repair strategy for nouns and adjectives on one hand and verbs on the other also suggests that Dagbani nouns and adjectives constitute a more privileged class than verbs, as already discussed in Section 1.2.

\subsection{Bound root nasals}

The data in (16) illustrate the effects of NPA on bound nominal roots in simplex nouns.

(16) Effects of NPA on nominal/adjectival roots: Simplex words

\begin{tabular}{|c|c|c|c|c|}
\hline a & $\begin{array}{l}\text { UR } \\
\text { /abi?[ílm-/ }\end{array}$ & $\begin{array}{l}\text { Singular } \\
\text { abí?ín-lí }\end{array}$ & $\begin{array}{l}\text { Plural form } \\
\text { abí?ím-á }\end{array}$ & 'lion’ \\
\hline & /wòPlím-/ & wò?lín-lí & wòPlím-á & 'boil' \\
\hline & /sál[í]m-/ & sál[î́]n-lí & sálm-á & 'gold' \\
\hline & /zìll[ì]m-/ & zìl $[\grave{i}] \mathbf{n}-\mathbf{l i}$ & zìlm-á & 'tongue' \\
\hline & /kpár[í]m-/ & kpár[í]n-lí & kpárm-á & 'cheek' \\
\hline$f$ & /tgó?[í]m-/ & fó?[í]]y-gú & tó?m-á & 'weak' \\
\hline
\end{tabular}

In (16), the plural forms of the roots end with $/ \mathrm{m} /$ before the plural nominal suffix -a. The lack of a buccal place of articulation for the plural nominal morpheme means that the place of articulation of the root-final nasal is underlying and independent of the place of any neighbouring segment. In the singular forms, the root-final nasal shares the same place of articulation with the onset of the suffix, an indication of assimilation to the suffix onset.

In (17), NPA takes place along with a coalescence with the onset of singular nominal suffix -gá, a deletion of the suffix vowel and a lengthening of the resulting root-final velar nasal (17a-d). In (17a-c), the vocalic deletion and nasal lengthening are optional. 
(17) NPA with suffix onset deletion: Simplex words UR singular plural form
a. kòN
kòn-gá [kòyá]/[kòń:]
kòn-sí
'leper'
b. zóN
zón-gá [zóyá]/[zóń:]
zón-sí
'bat'
c. bùN bòn-gá [bòyá]/[bòñy:]
bùn-sí
'donkey'
d. sùm sòm-gá [sòñ:]
sùm-á
'good'
e. póm póm-gá [póń]
póm-á
'rotten'

The singular and plural forms in (17a-c) and the complex words in (18d) also show that the underlying place specification of the nasal can not always be determined. The behaviour of nominal and adjectival roots is not different regardless of whether the root occurs in a simplex or complex word. The root-final nasals are subject to NPA both from suffix onsets in simplex words and from onsets of following roots in complex words.

\section{(18) Effects of NPA on nominal/adjectival roots: Complex words}

\begin{tabular}{|c|c|c|c|c|}
\hline UR & complex words & & & \\
\hline $\ln \sigma^{\prime}$ & bíy-káh-lí & bím-bíl-á & bín-títá-lí & bíñm-ŷmá-á \\
\hline $11 \mathrm{~g}$ & 'unripe thing' & 'small thing' & 'big thing' & 'short thing' \\
\hline b, du:n 'knee' & dù:y-kò-?ú & dù:m-bí-á & dòn-títá-lí & dùn-jón \\
\hline & 'slim knee’ & 'knee cap' & 'big knee' & 'stinky knee' \\
\hline c. zon 'bat' & $\begin{array}{l}\text { zòn-kúr-lí } \\
\text { 'old bat' }\end{array}$ & $\begin{array}{l}\text { zòm-bíl-á } \\
\text { 'small bat' }\end{array}$ & $\begin{array}{l}\text { zòn-títá-lí } \\
\text { 'big bat' }\end{array}$ & $\begin{array}{l}\text { zòn-yáý } \\
\text { 'female bat' }\end{array}$ \\
\hline d. laN 'net' & $\begin{array}{l}\text { lày-wóPín-lí } \\
\text { 'long net' }\end{array}$ & $\begin{array}{l}\text { làm-pèl-lí } \\
\text { 'white net' }\end{array}$ & $\begin{array}{l}\text { làn-títá-lí } \\
\text { 'big net' }\end{array}$ & $\begin{array}{l}\text { làn-jón } \\
\text { 'stinky net' }\end{array}$ \\
\hline
\end{tabular}

The behaviour of nasals in these bound units contrasts with the observed pattern in free standing words. Section 3.4 shows this contrast.

\subsection{Word-final nasals}

Like nominal and adjectival roots, nasals of different place specifications may surface at the right edge of a verb. Unlike nasals in nominal and adjectival roots, verb-final nasals always have underlying place specification which is maintained in all contexts. Where the verb root is followed by a suffix or clitic to form a phrase, the root maintains its category as a word. In other words, nasals at the right edge of verb roots are not targets of assimilation from potential triggers outside of the word domain. The data in (19) illustrate this in different morphological contexts. The suffixes -da and -ja respectively 
mark the imperfective and perfective aspects while -bv and -sim derive nouns from verbs. In the rightmost collumn are verb phrases, where the verbs are preceded by various particles.

\section{(19) Verb morphology}

\begin{tabular}{|c|c|c|c|c|c|}
\hline \multicolumn{6}{|r|}{ PHRASE } \\
\hline \multicolumn{6}{|r|}{ kòy lí 'lose it' } \\
\hline b. bàn & 'know' & bày-dá & bày-já & bày-sîm & bày bá 'recognise them' \\
\hline c. tàn & 'forget' & tàm-dá & tàm-já & tàm-sîm & tàm lí 'forget of it' \\
\hline d. dìm & 'bite & dìm-dá & dìm-já & dím-bû & dìm só 'bite someone' \\
\hline e. $\mathbf{g}$ & ua & gbàn-dá & gbàn-já & gbán-bû & gbán kó 'squat-farm’ \\
\hline
\end{tabular}

Unlike the data in (16)-(18), in (19), NPA is blocked, and nasals bear independent place specifications. This asymmetry in the application of the rule can be understood when the morphological units the nasals surface in are examined. In (16), (17) and (18), the assimilated nasals surface at the right edge of morphologically bound units: affixes, clitics and bound roots. In (19), the nasals are at the right edge of free standing words.

The argument here is not necessarily about segments within verbs resisting assimilation which nouns and adjectives undergo. The argument is that, the word as a morphological unit is a strong position. The featural composition of segments within it are protected from any contrast-neutralising change or loss that may be triggered across its boundary. This is supported by the behaviour of nasals at the right edge of fully derived nouns and adjectives, as observed in associative compounds, shown in (20).

\section{(20) Associative construction}

\begin{tabular}{|c|c|c|c|c|}
\hline & possessor & possessed & compound & \\
\hline a. & /kòn-gá/ [kòń:] & bí-á & kòn bí-á & 'a leper's child' \\
\hline b. & /zón-gá/ [zóń:] & nápóy & zóý: nápóy & 'a bat's foot' \\
\hline c. & /bùn-gá/ [bùñ:] & tàpà?-á & bòn tápá?-á & 'a donkey's cheek' \\
\hline d. & [dàgbán-â] & bí-á & dàgbán bí-á & 'a Dagomba's child' \\
\hline e. & [kòm: ] & dǔ: & kòḿ dú: & $\begin{array}{l}\text { 'a water room' (room } \\
\text { for water storage) }\end{array}$ \\
\hline
\end{tabular}

The first lexical roots in (20a-c) are the same as those in (17a-c). In (20), NPA applies in the singular forms as it does in the singular and plural forms in (17). Unlike the complex words in (18), the first lexical root in (20) maintains its nominal suffix, making it a complete word and opaque to NPA. This opacity is observed even in cases of vocalic deletion and compensatory lengthening of preceding nasals (20a-c). The compound in 
(20d) also demonstrates that the non-assimilation is not due to the nasal having already undergone assimilation in the singular root form. Indeed, the underlying form of 'a Dagomba's child' is dàgbán-a bí-á. The suffix -a undergoes a non-phonological deletion with no concomitant effect on preceding nasal, leaving the underlying coronal $/ \mathrm{n} /$ exposed to the following root-initial /b/. In spite of this, the nasal maintains its place specification. The position of dàgbán as a complete word in the compound can be contrasted with dàgbán- as a bound root in the complex word dàgbám bí-á 'a Dagomba child', where the morphological absence of suffix -a makes the root-final nasal a target of NPA ${ }^{3}$.

In sum, the discussion of NPA in this section has demonstrated that it is a good diagnostic in defining the distinction between words and subwords in two ways. First, in sub-words, the place of articulation of nasals may not be specified; in words, the places of nasals are fully specified. Second, a nasal at the boundary of a bound unit assimilates to the place of a following consonant. At the boundary of a free standing word, it maintains its specified places of articulation when preceding suffixes, clitics or lexical roots. Section 4 shows further diagnostics in defining the boundary between words and sub-words.

\section{Other phonological processes}

The processes discussed in this section are vowel harmony (based on ATR, height, and rounding features) and dissimilation through lateral deletion. Given that the discussion is aimed at demonstrating how these processes serve as diagnostics in defining the distinction between words and sub-words, no exhaustive theoretical analysis of any of the processes is provided.

\subsection{ATR and height harmony patterns}

In Dagbani [ATR] harmony, two broad patterns have been observed in previous research (Hudu 2010, 2012, 2013). One is a progressive pattern of harmony triggered by /i/ and targetting high [-ATR] vowels that surface in suffixes, enclitics or as epenthetic vowels. The other is a regressive pattern triggered by the mid vowels $[\mathrm{e}, \mathrm{o}]$ and targetting non-high root vowels. Both spreadings are bounded by the limit of one lexical root

\footnotetext{
${ }^{3}$ In Hudu (2010), I argue that the surfacing of (20d) kòm: with a long nasal is a diachronic processes of deletion of the singular nominal vowel suffix and compensatory lengthening of the root vowel. This argument is based on a comparison with similar nouns where the deletion and lengthening are clearly synchronic, (as in 20a-b), and the plural form of the noun which bears the falling tone on the nasal in the root (kòm-â.)
} 
morpheme and adjacent affixes and clitics. In other words, a root vowel may trigger harmony targetting vowels in non-lexical morphemes and vice versa. A vowel of one lexical root is not a target of harmony triggered by a vowel of another lexical root, as harmonic feature spreading does not cross the boundaries of two lexical roots.

The data in (21) show word pairs with the same suffixes or epenthetic vowels. The non-root vowels are always [-ATR] except when the root vowel is /i/. Those in (22) show that epenthetic and clitic vowels are targets of harmony also triggered by /i/. The second $\mathbf{m i}$ in (22c) is a predicate focus marker. Both datasets illustrate the first broad pattern of harmony.

(21) /i/ as trigger of left-to-right [+ATR] harmony (Cited from Hudu 2013, 2014)
Root-to-affix harmony
[-ATR] roots
a. pín-î
'gift-sg.'

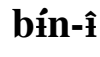
'thing-sg.'
b. dí?-í
'mirror-sg.'
dư?í
'cook.V'
c. tí-bû
'vomit-imperf.'
dá-bô
'buy-imperf.'
d. dí-h[í]-bû
dól[îi]-b̂̂ 'follow-imperf.'
e. vìh[ì]
'investigate. $V$ '
gbáh[î]
'catch (many)'
f. píh[í]g[î] 'postpone.V'
póh[í]g[î̀] 'pluck.V'
g. jí?[í]
'fly. V'
já?[í]
'jump over.V'

(22) Epenthetic and clitic vowels as targets of [+ATR] harmony (Hudu 2013)
a. lìh[ì] tí 'look at us'
b. kpíhí-bû 'extinguish-imperf. (fire)'
c. mì mî
'know foc.'
d. zìn ní 'sit there'
e. vìh[ì] mì tî 'investigate focus us (investigate us)'
f. kpín ní 'in (the month of) Kpini’

The other pattern is illustrated by the data in (23) and (24). (23) show that mid vowels in non-final position are [-ATR] except when the domain ends with another mid vowel. In (24), the target vowel is /a/. 
(23) Word-final [o, e] as harmonic triggers

\begin{tabular}{|c|c|c|c|}
\hline \multicolumn{2}{|l|}{ [-ATR] roots } & \multicolumn{2}{|c|}{ suffix-to-root harmony } \\
\hline a. dór-tí & 'disease-pl.' & dór-ó & 'disease-sg.' \\
\hline b. tgòr-t̂̂̀ & 'blow-pl.' & tgòr-ê & 'blow-sg.' \\
\hline 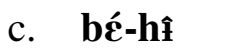 & 'shin-pl.' & bé-é & 'shin-sg.' \\
\hline d. $\quad \mathbf{k j ̀ h}[\mathbf{i}]$ lí & 'sell it' & kòh ó & 'sell it (anim.)' \\
\hline e. bé-Pú & 'bad/ugly one-sg.' & bé-é & 'mischievous person-sg.' \\
\hline f. $\quad 3 \grave{\varepsilon}-? \tilde{u}$ & 'reddish-sg.' & 3è̀-é & 'red-sg.' \\
\hline g. kòr-ŝ̂ & $\begin{array}{l}\text { 'interests/ } \\
\text { temptation' }\end{array}$ & kòr-ê & 'desire' \\
\hline
\end{tabular}

(24) [+ATR] low vowel before final mid vowel (cited from Hudu 2013)
a. dà lí 'buy it'
[dà ó] 'buy it (animate)'
b. bá lî̀ 'ride it'
[bá ô] 'ride it (animate)'
c. kál-tí
'enamel ware-pl.'
[kál-ó]
'enamel ware-sg.'
d. pál-á
'new-pl.'
[pál-ó]
'new-sg. (animate)'
e. sàl-á 'human'
[sà̀l-ô]
'human-pl. (crowd)'
f. tàdáb-tî 'writing ink-pl.'
[tằdáb-ô] 'writing ink-sg.'
g. tàtáb-t̂̂ 'the like of-pl.'
[tạ̀tăb-ô] 'the like of-sg.'

In addition to these observations, Dagbani has a pattern of harmony in which the root vowel agrees both in height and [+ATR] with a suffix /i/. The suffix -i/-hi is the trigger of harmony targetting an underlying non-high or [-ATR] root vowel.

(25) Plural nominal suffix as trigger in [+ATR] and [+high] harmony patterns

$\begin{array}{lllll} & \text { Roots } & \text { singular } & \text { plural } & \\ \text { a. } & \text { kpá:n- } & \text { kpán-gá [kpáí:] } & \text { kpín-î̀ } & \text { 'guinea fowl' } \\ \text { b. } & \text { wàr- } & \text { wàh-ú } & \text { jùr-î̀ } & \text { 'horse' } \\ \text { c. } & \text { náP- } & \text { náh-ó } & \text { ní?-î̀ } & \text { 'cow' } \\ \text { d. } & \text { ká- } & \text { ká-hí } & \text { têî̀ } & \text { 'guinea corn' } \\ \text { e. bìl- } & \text { bíl-á } & \text { bí-hí } & \text { 'small' }\end{array}$

There are two plausible analyses of this pattern. The analysis implied in the presentation of the data in (25) is based on the assumption that the root vowel is underlyingly low. The basis for that assumption is the singular forms in (25), all of which have low vowels except (25e), which would have an underlying / $\mathbf{i} /$. Under this analsyis, the suffix /i/ changes root ([+low]), [-ATR] vowels into [+high, +ATR]. In some cases, it results in a complete neutralisation with the suffix vowel. The main point of difference, then, between the root forms in (25), which are sub-words under the present analysis, and 
full words is that, there are no instances of vowels in full words undergoing harmony triggered by a clitic that changes the height specification of the root vowel or leads to a height neutralisation with vowels of different height specification. This asymmetry is discussed further below.

An alternative analysis of the data is one that invokes the notion of underspecification. In an underspecification approach, the vowels in (25) are assumed to be not underlyingly specified for the vocalic features [high, low, ATR]. This approach becomes clearer when we consider the data in (25) again, with an additional word that does not display [+ATR] or [+high] harmony, as illustrated in (26).

(26) Non-specified segmental features?

UR. Root sg. form pl. form

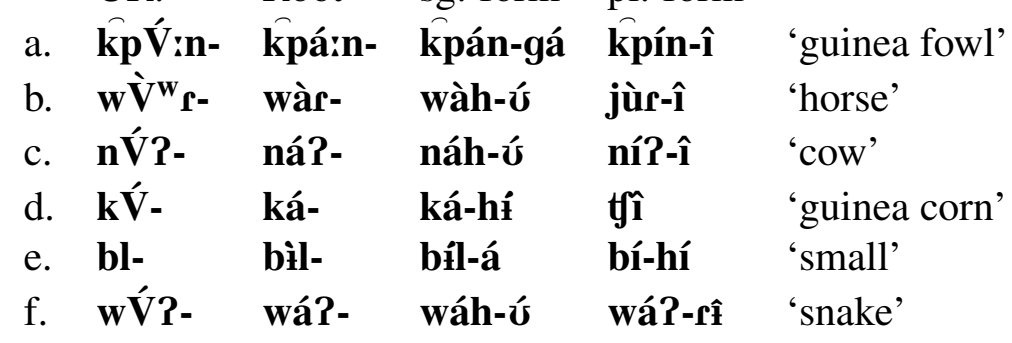

With the exception of (26e), the form of the root vowel in a larger construction and in the singular form is always [a]. In the plural form, it is a high [+ATR] vowel, [i] or $[\mathrm{u}]$, in harmony with a plural nominal suffix vowel [i]. When the plural nominal suffix vowel is not [i], the root vowel surfaces as [a], as in (26f). When viewed as a case of underspecification, the surfacing of [a] in the root and in [-ATR] contexts can be attributed to a sonority effect. The vowel /a/ surfaces because it is the most sonorous [-ATR] vowel to harmonise with the vowel in the singular morphemes and the plural form in (26f). This is supported by the fact that in Dagbani, vowel alternations lead to sonority enhancement in non-final positions and reduction in final positions. For instance, Hudu $(2010,2013)$ show that underlying mid vowels / $\varepsilon$, o/ surface phonetically as [a] in non-final position. In domain-final positions, the same vowels surface as $[\mathrm{e}, \mathrm{o}]$.

In the plural forms, the realisation of the vowel is driven by a harmony consideration, producing the most harmonic [+ATR] vowel [i] to harmonise with plural /i/. In (26b), the realisation of the root vowel as $[\mathrm{u}]$ in the plural form is due to an underlying specification for [+round]. In the singular and complex noun forms, the underlying rounding does not have an effect because Dagbani lacks rounded low vowels. In (26d), suffixing the plural nominal -i to a codaless root results in an underlying vowel hiatus $\mathbf{k} \mathbf{V}-\mathbf{i}$. This is resolved by a coalescence in which [i] expectedly becomes the surface vowel (kî)), as the root vowel has no underlying featural specification for height 
or [ATR]. The underlying root $[\mathrm{k}]$ changes to [ $\mathrm{g}]$, a regular pattern of palatalisation of velar consonants before front vowels in Dagbani (Olawsky 1999; Hudu 2010).

The surface vowels in the words bíl-á and bí-hí in (25e) apparently make these words exceptions to the underspecification analysis just presented. However, the adjective 'small' is unique in a different way. The noun bí-á 'child-sg.' has the same plural form (bí-hí) as the adjective bíl-á. However, unlike bí-hí 'small-pl.', in bí-hí 'childpl.', the root vowel is clearly the trigger of [+ATR] harmony, as is the case in Dagbani regular progressive [ATR] harmony shown in (21) and (22). In the underspecification analysis of this word, there is no underlying root vowel. In its singular form, [i], the regular epenthetic vowel in Dagbani, is inserted. In the plural form, this epenthetic vowel harmonises with the plural nominal suffix vowel.

The underspecification account is further supported by several observations within the phonology of Dagbani. First, [+ATR] harmony neither changes the height specification of target vowels nor leads to complete assimilation to the trigger, unless both trigger and target have the same underlying height feature specification. This is discussed extensively by (Hudu 2010). In particular, low vowels remain low when targeted by mid vowels in [+ATR] harmony, as already shown in (24). Thus any other account of how the vowels in the plural forms in (25) surface as [+high] is difficult to motivate, as it is inconsistent with the observed pattern of [ATR] harmony in Dagbani.

The second source of support for underspecification is the opacity of the low vowel to harmony triggered by a high vowel. This is shown in (27), where harmony fails to take place. If the underlying vowels in (25) were specified for [+low], the root [+ATR] harmonic forms would not have surfaced.

(27) Low vowel as non-targets of [ATR] (cited from Hudu 2013)
a. pí â
*[pí ậ]
'bury you'
b. bí-á
*[bí-á⿴囗十
'child-sg.'
c. tì bá
*[tì báa
'give them'
d. dìm-á
*[dìm-áa]
'eat-imper.'
e. kpím-á
*[kpím-á]
'dead person-sg.'
f. vìh á
*[vìh á]
'investigate you'
g. kpìh[ì]-má
*[kpìhì-má]
'put off-imper.'

The final observation supporting underspecification is the fact that height harmony resulting in [-high] vowels surfacing as [+high] is not observed anywhere else in the phonology of Dagbani. This provides little motivation for the argument that the apparent pattern of height harmony observed here is part of a systematic harmony pattern in Dagbani. 
The goal of this rather lengthy discussion is to show the unusual nature of the harmony patterns in (26). When viewed within the context of the vowel harmony system of Dagbani, especially compared with the data in (24), the height harmony is not expected. Yet the differences between the morphological units that hold the target vowels provide an answer to the apparent inconsistency. In (26), the height-harmonising vowels are located in nominal roots, bound units. In (24), the height-opaque vowels are located in verbs, free standing words. These observations lead to two generalisations similar to those that were reached in the discussion on NPA. First, vowels in a sub-word may not be fully specified for all features, unlike vowels in a full phonological word. Second, the height harmony of a root vowel to the suffix trigger takes place because the nominal/adjectival root is not a full phonological word. Harmonic target vowels that surface in full words, such as those in (24) do not change their height specification. In other words, height harmony is restricted to targets in bound units (sub-words). This generalisation holds whether underspecification is assumed or not.

\subsection{Rounding harmony}

Rounding harmony is manifested in reduplicated as well as non-reduplicated forms. In reduplicated forms, it is a root-controlled process, regressively targeting vowels in a reduplicant prefix and the vowel of a fixed IVN syllable. Sample data are shown in (28) and (29), where the reduplicants are underlined. The data in (29) lack synchronic non-reduplicated forms, unlike the forms in (28). In (29), the fixed syllable is itallicised.

(28) Rounding harmony
a. kpìl-lí
'round'
kpì-k̂̀il-lí
'portably round'
b. /kpàn-gá/ [kpàń:]
'wing'
kpìnm-kpàñ:
'(mature) wing'
c. /bòn-gá/ [bòń:]
'darkness'
bùm-bòń
'extreme darkness
d. /pòngó/ [pòyó]
púm-póyó
'right now'

(29) Rounding harmony

a. púm-póy-ţí-hí 'strychnos fruit-pl' (Blench 2004)

b. dòn-dòñ: 'court yard'

c. kpí-lín-kpí-hî 'epilepsy'

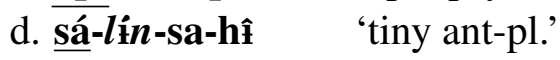

e. pò-lìm-pòñ: 'Sterculia Tomentosa' (Blench 2004)

f. kứ-lón-kú-hî̀ 'beetle-like insect-pl.' (Blench 2004)

The reduplicant vowel and the vowel of the fixed syllable are underlyingly $/ \mathbf{i} /$, as shown in $(28 \mathrm{a}, \mathrm{b})$ and $(29 \mathrm{c}, \mathrm{d})$, which lack round vowels in the base. In the remaining 
data, the reduplicant and all preceding vowels surface as $[\mho]$ because the base has [o] or $[\mho]$. In non-reduplicated forms, domain-final $[\mathrm{o}, v]$ are the triggers, targeting a root or epenthetic [i].

(30) Rounding harmony
a. tớm-ô
'messenger-sg.'
cf. tìm
'send'
b. zứn-ô
'odd/alien/stranger-sg.'
cf. Zî̀y
'alienate'
c. tè:n lòrò
'unkempt thick beard'
cf. lìrìm
'to mess up'
d. sùm-ó
'bosom friend-sg.'
cf. sìm-nìmá
'friend-pl.'
e. báh[ú]-gú 'adder-sg.'
cf. báh[í]-sí
'adder-pl.'
f. bìlkò?[ú]n-ó 'villain-sg.'
cf. bílkó?[îi]n-sî̀ 'villainy'

The verbs tìm, zîn and lìrìm from which tứm-ô, zún-ô and lò̀ò are derived, provide evidence of underlying root/i/ in (30a-c). In (30d) the plural form of the noun has root $/ \mathbf{i}$ / when there is no domain-final round vowel. Unlike these root forms, the pattern shown in the examples with epenthetic $/ \mathrm{i} /$ becoming $[\mho]$ is not universal. Some speakers may lack these forms, and some epenthetic / $\mathbf{i} /$ may not get rounded. However, there is no contrast between $/ \mathrm{i} /$ and $/ \mho /$ in epenthetic position when the domain-final vowel is round. In other words, whether these forms are produced with $/ \mathbf{i} /$ or $/ \mho /$, their meanings remain the same, in spite of these two vowels being contrastive in lexical roots.

Of interest to the discussion here is the apparent opacity of the same vowel to rounding harmony when it surfaces in verb roots.

(31) No Rounding harmony
a. tìm ó *tòm ó
b. zín ó
*zón ó
'send him/her'
c. sín ó
*sún ó
'alienate him/her'
d. dìm ó
'treat him/her with contempt'
e. tìr ó
*dòm ó
'bite him/her'
f. mírí-b̂̂
*tòr ó
'point at him
*míru-bû
'getting close'

The phrases tìm ó in (31a) and tớm-ô (30a) have the same underlying segmental sequences (/tim o/). Similarly, zín ó (31b) and zón-ô (30a) have /zín o/ as their underlying form. The only reason rounding harmony fails in the forms in (31) is the word boundary between the trigger and the target. The similarity between rounding harmony in reduplicated forms and the non-reduplicated forms is quite obvious. In all cases where rounding harmony applies, the target vowels are located in bound nominal roots, reduplicant and fixed affixes, all of which are bound forms. The behaviour of segments 
in these units stands in sharp contrast to those located in the words tìm and zín whose vowel is not a target of rounding harmony. Thus rounding harmony provides evidence that the bound morphological units pattern together as undergoers of a process triggered across their boundaries.

\subsection{Lateral deletion}

Lateral deletion applies in a number of contexts in Dagbani as a means of blocking adjacent coronal consonants. As in the phonological processes already discussed, whether dissimilation occurs or not depends on the morphological category in which the lateral consonant occurs. In one context, a nominal/adjectival root-final $/ 1 /$ is deleted when followed by a suffix with initial /j/, (32).

(32) Deletion of /l/ in nominal roots

\begin{tabular}{|c|c|c|c|c|}
\hline & UR & singular & plural & \\
\hline a. & jíl & 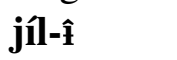 & jí-jâ & 'house' \\
\hline b. & gál & gál-í & gá-já & 'thread' \\
\hline c. & gbál & 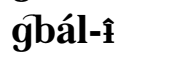 & gbá-jâ & 'leg' \\
\hline d. & gól & gól-̂̂̀ & gó-jâ & 'moon' \\
\hline e. & zòngòl & zò̀ngưl-í & zò̀ngư-já & 'clitoris' \\
\hline f. & dàgòl & dàgứl-í & dàgứ-já & 'merchandise' \\
\hline g. & kàl & 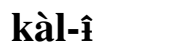 & kà-jâ & 'tradition' \\
\hline h. & jèvíl & nèvíl-î & jèví-jâ & 'soul' \\
\hline 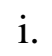 & tà:ntfil & tà:ntfíl-í & tà:ntyí-já & 'woman's loin cloth' \\
\hline
\end{tabular}

This contrasts with the observed pattern in verb morphology. When the perfective aspectual suffix [-ja] follows a verb that ends with [1], the lateral is not deleted.

(33) No root-final /l/ deletion before perfective marker -ja
a. pill[i]
pìl-já 'start'
b. bíl[í $]$
bìl-já 'rape'
c. kứl[í] kùl-já 'go home'
d. wól[í] wòl-já 'bear fruit'
e. dèl[ì] dèl-já 'dry.V'
f. vál[í] vàl-já 'swallow'
g. màl[ì] màl-já 'make'
h. jíl[1̂] jill-já 'sing'

The nominal/adjectival roots pattern with suffixes as domains where /1/ is deleted. In singular and plural nominal suffixes, $/ \mathrm{l} /$ is deleted when preceded by a root-final $/ \mathrm{n} /$. This is shown in the third column of the data in (34), along with NPA. 
(34) NPA, /1/ deletion and vowel shortening

\begin{tabular}{|c|c|c|c|c|}
\hline UR & $\begin{array}{l}\text { UR sg. } \\
\text { (NPA) }\end{array}$ & $\begin{array}{l}\text { surface sg. } \\
\text { (l-deletion) }\end{array}$ & \multicolumn{2}{|c|}{$\begin{array}{l}\text { surface pl. } \\
\text { (V-shortening) }\end{array}$} \\
\hline a. ju:m & /jù:n-lí/ & [jù:n-í] & jòm-á & 'year' \\
\hline b. tu:m & /tú:n-lì/ & [tú:n-í] & tứm-á & 'work' \\
\hline ta:m & /tá:n-lí/ & [tá:n-í] & tám-âa & 'shea nut' \\
\hline ma:m & /má:n-lí/ & [má:n-í] & mán-â & 'okra' \\
\hline mo:m & /mó:n-lí/ & [mó:n-í] & móm-á & 'ripe' \\
\hline go:m & /gò:n-lí/ & [gò:n-í] & gòm-á & 'wall' \\
\hline be:m & /bé:n-lí/ & [bé:n-í] & bém-á & 'shin' \\
\hline kpe:m & /k̂́pé:n-lì/ & [k̂éé:n-í] & kpém-á & 'strong' \\
\hline ku:m & /kúun-lí/ & [kú:n-í] & kúm-á & 'dry' \\
\hline
\end{tabular}

In (34), underlying nominal/adjectival CV:m roots become CV:n in singular forms due to NPA triggered by an abstract singular suffix onset lateral. The roots surface with $[\mathrm{m}]$ in the plural forms with suffix $\mathbf{- a}$, which does not have an onset that could change the place of articulation of the root nasal. This gives an indication that $[\mathrm{m}]$ is the underlying nasal at the right edge of the root. The only reason this underlying $[\mathrm{m}]$ surfaces as [n] is an underlying suffix onset /l/. This onset remains abstract because it deletes after triggering NPA onto the root-final nasal. These nouns are thus similar to the data shown in (16), Section 3, (e.g. gbí?ín-lí/ gbí?ím-á 'lion') which also show underlying root-final [m] surfacing as [n] due to NPA to suffix onset [1]. The difference between the data in (16) and those shown in (34) is that, in the former, no suffix-onset deletion takes place.

If lateral deletion had not taken place, the resulting surface form would have featured a sequence of two coronal consonants. In (32), the lateral is deleted to avoid a sequence of [1] and [j], both of which are coronal. Similarly, a sequence of [1] and [n] are avoided through lateral deletion in (34) because both are coronal. The deletion of [1] both as a root coda and suffix onset is needed to avoid such a sequence of two consonants sharing the same place of articulation. Deletion is used in this context to achieve dissimilation, driven by the Obligatory Contour Principle (Leben 1973; McCarthy 1988), defined in (35).

(35) Obligatory Contour Principle (OCP) (McCarthy 1988:88):

Adjacent identical elements are prohibited.

The differences between the data in (33), where OCP violations are tolerated, and those in (32) and (34) where the avoidance of coronal sequences triggers lateral deletion 
is at the heart of the discussion here. The conclusion is that, an OCP effect compromises the segmental or featural composition of a morphological unit. Thus the application of OCP is an indication of the relative positional strength of various morphological positions, such that morphemes that display equal strength are subject to the same generalisation with respect to OCP and those that display unequal positional strength are subject to different genralisations - segments in non-previliged positions undergoing OCP effects blocked from segments in previliged positions. ${ }^{4}$

In sum, the discussions in this and the preceding section point to the generalisation that affixes, clitics and bound lexical roots pattern together in permiting contrastneutralising phonological processes triggered across their boundaries, as opposed to free standing words, which block these processes. This assymetry forms the basis for the conclusion that NPA, vowel harmony and OCP are diagnostics for defining the distinction between a full word and a sub-word. I conclude the description and analysis with a summary of the various morphological units in Dagbani which, based on evidence from the application of the processes discussed, constitute phonological words.

(36) A morphological unit that constitutes a phonological word in Dagbani

a. A verb root (e.g. dì 'eat', pìlì 'start').

b. A suffixed verb (dí-bû 'eating', pìl-já. 'started')

c. A verb with a clitic (e.g. n dì to eat, pìl lí 'start it').

d. A simplex noun/adjective (e.g. bíl-á 'small-sg.', bí-hí 'small-pl.').

e. A nominal root with two or more affixes (e.g sá-lín-sá-hî 'tiny ant-pl.').

f. A complex noun/adjective (e.g. nà-bì-pò?ín-zé-é 'a fair coloured princess').

g. A noun/adjective with a clitic (e.g. m bí-á 'my child-sg.').

With the exception of the verb root in (36a), each of the phonological words consists of two or more morphemes: a lexical root combined with one or more affixes or clitics. And with the exception of the verbs in (36a-c), no morpheme in any word can independently pass for a word except in combination with one or more other morphemes. On the other hand, the words in $(36 \mathrm{a}, \mathrm{d}, \mathrm{e})$ are the only words with the minimal number of morphemes in their respective categories to form a phonological word. All the remaining word forms contain an affix or clitic added to a minimal phonological word.

The list further becomes more insightful when some of the phonological words are compared with other morphological units that are not in the list. For instance, while the verb root dì 'eat' is a word, the nominal root bí in bí-á 'child-sg.' is not. Again, the

\footnotetext{
${ }^{4}$ While this proposal makes sense, there is obviously the need for a more detailed research and analysis given that adjacent coronals are observed in other bound morphemes, as can be seen in the data on NPA. Perhaps this is just a tendency, as OCP itself is, in general.
} 
complex noun nà-bì-pù?ín-zé-é with four nominal/adjectival roots is only one phonological word. By contrast, the compound noun dàgbán bí-á 'a Dagomba person's child' which has only two nominal roots has two phonological words.

Section 5 provides a formal account of NPA to illustrate how the asymmetry between the morphological units discussed in the preceding sections is accounted for using the theory of positional faithfulness within Optimality Theory.

\section{Formal positional faithfulness account}

A major claim in the preceding sections is that, the asymmetrical application of the phonological patterns is due to differences in the relative strength of various morphemes. This section presents a formal analysis of the asymmetries based on the theory of positional faithfulness. The strength of the positional faithfulness approach relative to alternative approaches is not the focus of this paper, as the paper focuses more on the various processes, the role they play in defining the phonological word, and the unified analysis that they can be subjected to. Potential alternative approaches are not ruled out.

\subsection{Analysis of nasal place assimilation}

Analysis of NPA has to take into account the cross-linguistically diverse environments in which the process takes place. The most common environment is the coda position or the right edge of a syllable boundary preceding another consonant. This is the case for the Dagbani patterns discussed here. However, NPA may affect nasals that are not preconsonantal nor contiguous to the licensing consonant, as in the German example haben $\rightarrow$ habm, the Spanish example Adam $\rightarrow$ adan and the English examples such as kent, hampton (Padgett 1995). For the purpose of the analysis in this paper, elements of two approaches to analysis of NPA are assumed. One approach is based on Feature Geometry (e.g. Archangeli and Pulleyblank 1994; Padgett 1994) which views NPA as resulting from a rule inserting an association line (path), leftwards from the place of a stop to that of a nasal. This forms the basis for the constraint NPA.

(37) NPA: Place on a path to a [+nasal] segment must be linked to a place on the path to another segment.

The other approach is the licensing approach, rooted in prosodic principles (Goldsmith 1990) and built on the hypothesis that a segment must be specified for a place feature. This has been expressed as a Have Place or SPECIfy Place constraint in past studies (e.g Itô and Mester 1993; Padgett 1995, 2002; Pulleyblank 1997; Kim 2003; Beckman and Ringen 2004; Kim and Pulleyblank 2009). 
(38) SPECIFY-PlaCE: Every segment is specified for some Place feature (SPEC-PlaCE)

Regardless of their relative ranking, the combined effects of these two constraints ensure that (i) every nasal surfaces with a place of articulation and (ii) the place of articulation of a nasal is shared with another segment. This is shown in (39).

Effects of NPA and SPEC-PlACE
\begin{tabular}{|r||c|c|}
\hline N bá & NPA & SPEC-PLACE \\
\hline \hline a. N bá & & $* !$ \\
\hline b. $\mathbf{n}$ bá & $* !$ & \\
\hline c. $\mathbf{m}$ bá & & \\
\hline
\end{tabular}

N bá (39a) has no place specification, which leads to a fatal violation of SPECPlace. (39b), on the other hand, fails to satisfy the constraint NPA, as the place specification of the nasal differs from that of the following consonant. (39c) is the optimal candidate because it satisfies both constraints.

The tableau in (39) shows the result of interaction of two constraints in deriving the surface place specification of a nasal with indeterminate underlying place feature. To determine the remaining constraints required for the analysis of NPA, there is the need to answer another fundamental question: why nasals with underlying place specification still lose their place specifications to following obstruents, whereas oral consonants in $\mathrm{NC}$ sequences maintain their place specifications.

\subsubsection{Nasals versus non-nasals in NC sequences}

Previous acoustic studies such as House (1957); Malécot (1956, 1960); Ohala (1975) attribute the differences in the behaviour of nasal and oral consonants in NC sequences to the weakness of nasals. Ohala notes "a step-function change" in both amplitude and spectrum in the transitions between a vowel and a nasal. Formant transitions of nasals in adjoining vowels are not as effective cues for differentiating place of articulation of nasals compared with the formant transitions of oral obstruents. Evidence from Sacia and Beck (1926), also shows that the large size of the surface area of the nasal cavity causes a damping of the sound in nasals which results in large bandwidths for nasal formants and anti-formants, and decreases the sound amplitude.

For the OT analysis of NPA and the other processes, I adopt the theory of correspondence McCarthy and Prince (1995) which enforces input segmental and feature preservation using a family of constraints known as faithfulness constraints. McCarthy 
and Prince's formulation of the theory includes three main faithfulness constraint categories that enforce resemblace between two strings such as input and output forms. These are MAXimality, DePENDENCY and IDENTITy, defined in (40).

(40) Correspondence constraints (McCarthy and Prince 1995:16)

a. MAX-IO: Every segment of the input has a correspondent in the output (No phonological deletion.)

b. DEP-IO: $\quad$ Every segment of the output has a correspondent in the input (Prohibits phonological epenthesis.)

c. IDENT-IO(F): Output correspondents of an input $[\gamma \mathrm{F}]$ segment are also $[\gamma \mathrm{F}]$. (Features may not be changed.)

Subsequent researchers using correspondence theory have proposed a conception of correspondence by which DEP and MAX constraints are applied to both segments and features, making IDENT constraints superflous (see for instance Itô et al. 1995, Pulleyblank 1996, 1997 Myers 1997). Thus any change in the featural specification of an input segment amounts to a deletion of the feature which can be penalised by a MAX constraint. Alternatively, any feature in an output segment that is not in the input correspondent amounts to an insertion of the feature, which may incur a violation of a DEP constraint. This approach is used for the analysis in this paper. The constraints that block changes in features are expressed as MAX or DEP constraints. The DEP constraints are shown in (41).

a. DEP-PL(N): The place specification of an output [+nasal] segment has an input correspondent.

b. DEP-PL(-N): The place specification of an output [-nasal] segment has an input correspondent.

The relative weakness of nasals motivates the ranking of DEP-PL(-N) above DEP$\mathbf{P L}(\mathbf{N})$. That ranking makes nasals the more likely to assimilate in NC sequences than oral segments. A crucial ranking also exists between the two constraints NPA and DEPPL(N) when the faithfulness constraints in (41) are added to the constraint set. As already noted, NPA requires a nasal to have its place linked to that of another segment. When the place specification of the licensing segment is different from that of the nasal, satisfying the demands of NPA will involve changing the underlying specification of the nasal, which in turn violates the demands of IDENT-PL(N). Thus the two constraints make potentially conflicting demands on the surface realisation of nasals with underlying place specifications. The fact that the nasal sound assimilates to the place of the 
neighbouring segment in such sequences implies that NPA outranks DEP-PL(N). However, this conflict (and others discussed below) is realised only when SPEC-PLACE is active. Its activity is required to avoid output forms that are unspecified for place. All nasals surface with a place specification, an indication that SPEC-PLACE is undominated in the language. The hierarchy is shown in (42).

\section{(42) SPEC-Place, DeP-Pl(-N), NPA » DeP-Pl(N)}

This hierarchy predicts nasals undergoing place assimilation, but not liquids or laryngeals. For instance, in a complex word, nasals at the right edge of lexical roots will undergo place assimilation, liquids and laryngeals in the same position will not. This is illustrated in (43) with the word /bín-káh-lí/ 'unriped thing-sg.'

/bín-káh-lí/ $\rightarrow$ [bín-káh-lí]
\begin{tabular}{|r||c|c|c|c|}
\hline /bín-káh-lí/ & SPEC-PLACE & DEP-PL(-N) & NPA & DEP-PL(N) \\
\hline \hline a. bíN-káh-lí & $* !$ & & $*$ & \\
\hline b. bín-kás-lí & & $* !$ & & $*$ \\
\hline c. bín-káh-lí & & & $* !$ & \\
\hline d. bín-káh-lí & & & & $*$ \\
\hline
\end{tabular}

In (43), bîN-káh-lí incurs a fatal violation of the SPEC-PLACE constraint because it has a consonant, the nasal, which is placeless. Given that all the input segments have place specifications, any output form with a place specification different from that of its input correspondent violates DEP-PL(N). However, such a violation may not be fatal because this constraint is dominated by DEP-PL(-N) and NPA. While the failure of the nasal in (43c) to assimilate incurs a fatal violation of NPA, the glottal fricative vacuously satisfies this constraint because it has no nasal feature. Changing its input place feature to agree with the suffix onset as in (43b) only leads to a needless violation of DEP-PL(N). Thus bín-káh-lí surfaces as the optimal form in spite of violating DEP-PL(N). This explains the asymmetric behaviour of nasals and non-nasals in identical environments.

\subsubsection{Blocking assimilation in privileged positions}

In Optimality Theory, contrast depends on the relative ranking of faithfulness and markedness constraints. Faithfulness constraints require maximal resemblance between input and output forms along some featural dimension; markedness constraints ban specific marked structures from surface forms without regard to their input specifications. This breeds potential conflict between the two constraint categories. Surface contrast is triggered in a language when faithfulness constraints outrank markedness ones while a reverse ranking leads to the neutralisation of contrast in a language. 
There have been two major approaches to analyses of positional asymmetry such as displayed in Dagbani. These are positional faithfulness and positional markedness accounts. In the positional faithfulness approach, the focus is on the use of faithfulness constraints that preserve the features of privileged positions. When these positionsensitive constraints outrank general markedness constraints, contrast is maintained in privileged positions. When such a ranking is integrated into another hierarchy in which the general markedness constraints outrank general faithfulness constraints, contrast is maintained only in privileged positions. In other positions, contrast between two segments is neutralised. Positional markedness, on the other hand, focuses on markedness constraints targeted at weak or non-privileged positions. The result of this is that, contrast neutralisation is confined to non-privileged positions while the privileged positions remain unaffected. While either approach could potentially account for the asymmetries discussed in this paper, only positional faithfulness is considered. ${ }^{5}$

The constraint hierarchy in (44) (Beckman 1998 etc.) represents a ranking schema in a positional faithfulness analysis of phonological asymmetries. FAITH(pos) represents a position-sensitive constraint, MARK is a markedness constraint that triggers changes in all positions, and FAITH is a general faithfulness constraint preserving contrast in all positions.

(44) Ranking schema for positional faithfulness analysis FAITH(pos) » MARK » FAITH

Given that NPA results in the loss of underlying place specification of nasals, a positional faithfulness constraint blocking NPA must militate against the loss of place specification for segments in strong positions. The constraint responsible for blocking assimilation across the boundary of a phonological word is DEP-PL $]_{w d}$, defined in (45).

(45) DEP-PL $]_{w d}$ : Within a phonological word, every output place specification has an input correspondent.

The existence of DEP-PL $]_{w d}$ also implies that of a general, context-insensitive faithfulness constraint to the place features of all segments, (DEP-PL). Since assimilation involves feature insertion, the constraint triggering it must rank above the one that blocks insertion. This motivates the ranking NPA » DEP-PL.

(46) DEP-PL: Every output place specification has an input correspondent.

\footnotetext{
${ }^{5}$ For details on the use of either approach, see Beckman (1998); Casali (1996); McCarthy and Prince (1995); Smith (2001); Zoll (1997, 2004) and others. See also Alderete (2003) on the problems with the use of positional markedness approach and Zoll (2004) on why positional markedness is preferred.
} 
It is important to note that the segment whose featural contrast is preserved with DEP-PL $]_{w d}$ may be a nasal. This breeds a potential conflict with the NPA constraint, which makes the opposite demand. The preservation of input specification for the place of nasals in phonological words is the result of ranking NPA below the positional constraint: DEP-PL $]_{w d} \gg$ NPA. Thus the ranking of the three constraints stands as DEPPL $]_{w d} »$ NPA » DEP-PL. Given that SPEC-PLACE and DEP-PL(-N) are undominated in the language, the ranking DEP-PL $]_{w d}$ " NPA implies that NPA ranks below SPECPlaCe and DeP-PL(-N) to produce the hierarchy in (47).

\section{SPeC-Place, DeP-Pl(-N), DeP-Pl $]_{w d} »$ NPA » DeP-Pl(N), DeP-Pl}

The tableau in (48) shows that with this ranking, the only acceptable surface form in NC sequences where the two segments belong to different phonological words is one in which the two segments are faithful to their underlying place specifications.

(48) No NPA across a phonological word: kòy bí-á 'a laper's child'

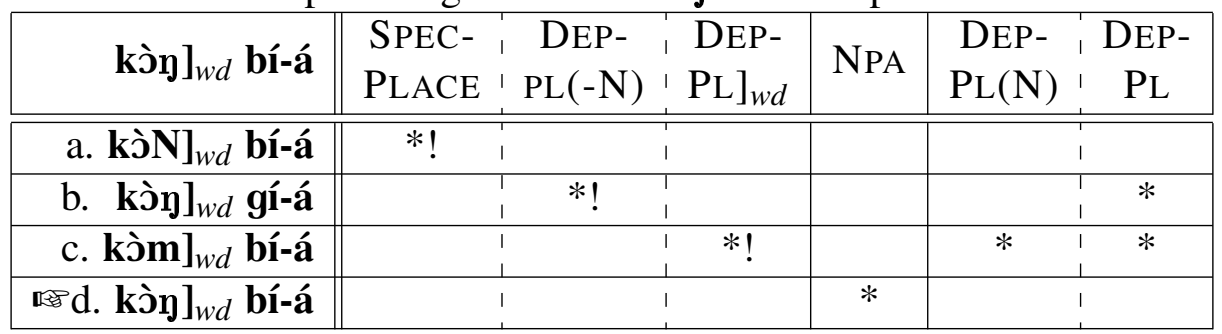

With DEP-PL(-N) and DEP-PL $]_{w d}$ now in the hierarchy, changing the place of a nasal through assimilation to the place of another consonant is no more optimal if the trigger and target are in different phonological words. This explains why kòm] $]_{w d}$ bí-á is ruled out. A possible means of achieving assimilation without changing wordfinal nasal place specification is to change the place specification of the following oral segment. However, that incurs a violation of undominated DEP-PL(-N), as in (48b). The only option left is to preserve the different place specifications of the segments in the NC sequence, at the expense of violation of the assimilation driving constraint NPA.

Section 5.2 takes a brief look at the outline of a positional faithfulness analyses of the remaining phonological processes discussed in this paper: vowel harmony and the OCP.

\subsection{Positional faithfulness in other phonological processes}

A positional faithfulness account of the remaining phonological processes discussed in the paper bears much resemblance to the analysis of NPA in the preceding section. As 
shown below, analyses of these processes are unified by (i) an undominated SPECIFY constraint for the relevant phonological feature, (ii) a markedness constraint that has the potential to change the underlying specification of the relevant feature, (iii) a general faithfulness constraint preserving the relevant feature, (iv) a position-sensitive faithfulness constraint preserving underlying specification of the relevant feature and (v) the positional faithfulness ranking schema in (44).

\subsubsection{Vowel harmony}

The outline of vowel harmony is illustrated here with rounding harmony. Formal analyses of harmony within Optimality Theory typically involve the use of a harmony driving constraint or constraint interaction that ensures that segments within the harmonic domain bear the same specification for the harmonic feature. In the positional faithfulness approach argued for by Beckman $(1997,1998)$, no such harmony driving constraint is needed. ${ }^{6}$ A positional faithfulness constraint interacts with other markedness constraints to derive harmony, in a way similar to the interaction that derives other positional asymmetric phonological patterns. What makes this possible is a proposal that in assessing output forms, markedness constraints are particular about the number of featural autosegments an output form contains, not the number of segments that bear the feature. For instance, in the word [túm-ô] 'a messenger', the two vowels together incur one violation of the markedness constraint against a surface form with the feature specification [+round] (*+ROUND) if both vowels are dominated by one [round] node, as in (49a). By contrast, the output form incurs two violations of *+ROUND if the two vowels are linked to two different [round] nodes (49b).

(49) Single versus double/multiple node domination

\begin{tabular}{|c|c|c|}
\hline [round] & b. [round] [round] & c. [round] [round] \\
\hline$\underset{\text { tứm-ô }}{\Lambda}$ & & \ìm ó \\
\hline
\end{tabular}

Having both vowels dominated by one [+round] node is thus a better way of satisfying the constraint. Indeed, such an association incurs the same number of violations as in (49d), where the [round] feature is associated with only one vowel. (49b) and (49c) are similar in the sense that each vowel is linked to only one [round] feature; they differ in the specifications of the vowels for rounding. In (49c), the two vowels have different specifications, in (49b), both are [+round]. (49d) shows an output form in

\footnotetext{
${ }^{6}$ Alternative approaches include featural alignment (e.g. Kirchner 1993), feature spreading (Walker 1998), feature agreement (Baković 2000), targetted constraints (Wilson 2003) Span Theory (McCarthy 2004)), Serial Harmony (McCarthy 2009) and others.
} 
which a vowel has no specification for round. Such an output form violates SPECIFY RoUND, which requires that every vowel has a specification for the feature [round]. In the tableaux below, such output forms are left out, along with the specifier constraints, which are only needed to rule out output forms which lack specification for the relevant features.

An important generalisation central to understanding the rounding harmony is that, it only targets [i]. This is the only vowel that does not have a distinct place specification: it is [-front, -back]. Thus changing [i] to any other vowel comes at a very minimal cost, compared to changing any other vowel in a harmony process. When viewed as a loss of vowel place feature, the rounding harmony pattern does not lead to a loss in an underlying place feature. The vulnerability of this vowel to harmony processes is further evident in the fact that it is the only vowel that is changed in both [ATR] and rounding harmony. As a suffix or epenthetic vowel, it becomes [i] when preceded by a root vowel [i]. The relative weakness of this vowel makes it a target of an implicational markedness constraint that says that non-front vowels be [+round], (50).

(50) -FRONT/ROUND: If [-front] then [+round].

While this constraint should be in a position to change an underlying / $\mathbf{i} /$ to [ $\mathrm{v}]$ in a rounding harmonic context, there are two things it should not be allowed to do: (i) change this vowel into [ $\mho]$ in non-harmonic contexts and (ii) trigger a $/ \mathbf{i} / \rightarrow$ i] change and satisfy the constraint vacuously. For instance, the word /tìm/ 'send' could either surface as [tòm] due to the force of this constraint or [tìm] to eliminate the feature that will make it a target of the constraint. These two liklely outcomes are blocked with the two faithfulness constraints in (51).

(51) a. DEP-COR: Every output [Cor] has an input correspondent [Cor].

b. DEP-ROUND: Every output [+round] has an input correspondent [+round].

As long as these two constraints outrank -FRONT/ROUND, underlying /i/ will remain unchanged in non-harmonic contexts, as shown in (52).

Faithfulness over markedness in non-harmonic contexts: /tìm/ $\rightarrow$ [tìm]

\begin{tabular}{|r||c:c|c|}
\hline /tìm/ & DEP-COR & DEP-ROUND & -FRONT/ROUND \\
\hline \hline a. tòm & & $* !$ & \\
\hline b. tìm & $* !$ & & \\
\hline c. tìm & & & $*$ \\
\hline
\end{tabular}


The difference between harmonic $/ \mathbf{i} / \rightarrow[\mho]$ and non-harmonic $/ \mathbf{i} / \rightarrow[\mho]$ is that, in the latter, the [+round] feature is inserted. In harmonic rounding, the [+round] feature already exists in the harmonic domain. Thus DEP-Round is not violated since there is no insertion of the [+round] feature. What changes is the extension of the association line from the domain-final round vowel to [i]. Pulleyblank (1996) refers to such output associations that do not exist in the input as DEPPATH violations. The relevant DEPPATH constraint is defined in (53).

(53) DEPPATH-Round: Any output path between [+round] and an anchor must have a correspondent path in the input.

The fact that harmony takes place is an indication that DEPPATH-ROUND ranks below -FRONT/ROUND, as shown in (54).

(54) Markedness over faithfulness in harmonic contexts: /tím ô / $\rightarrow$ [túm-ô]

\begin{tabular}{|c|c|c|c|c|}
\hline $\begin{array}{l}\text { [+round] } \\
\text { /tím-ô// }\end{array}$ & $\begin{array}{l}\text { DEP- } \\
\text { COR }\end{array}$ & $\begin{array}{l}\text { DEP- } \\
\text { ROUND }\end{array}$ & $\begin{array}{l}\text {-FRONT/ } \\
\text { ROUND }\end{array}$ & $\begin{array}{c}\text { DEPPATH- } \\
\text { ROUND }\end{array}$ \\
\hline 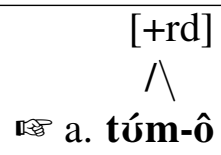 & & & & $* *$ \\
\hline 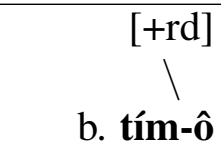 & $* !$ & & & $*$ \\
\hline $\begin{array}{c}\quad[+\mathrm{rd}] \\
\text { c. tim-ô }\end{array}$ & & & $* !$ & $*$ \\
\hline
\end{tabular}

With [+round] in the input, DEP-Round becomes inactive in (54), allowing the harmonic form in (54a) to surface as the optimal form, in spite of a double violation of DEPPATH-RoUnd. With this result, the analysis has accounted for the surfacing of contrastive / $\mathrm{i} /$ in non-harmonic contexts and harmonic targetting of the same vowel preceding final round vowels. What remains to be accounted for is the positional asymmetry, by which /ì/ is opaque to rounding harmony when it occurs in a word (/tím ó/ $\rightarrow$ [tìm ó] 'send him/her'). With the ranking schema of FAITH(pos) » MARK » FAITH, all that is required to derive opacity is for a positional faithfulness constraint to dominate the markedness constraint -FRONT/ROUND. This constraint is defined in (55).

(55) DEP-ROUND ${ }_{w d}$ : Every output [+round] in a phonological word has an input correspondent [+round]. 
(56) Positional faithfulness over general faithfulness: /tìm ó/ $\rightarrow$ [tìm-óo]

\begin{tabular}{|c|c|c|c|c|c|}
\hline \multirow{2}{*}{$\begin{array}{l}{[-\mathrm{rd}] \quad[+\mathrm{rd}]} \\
\left.\mid{ }^{\mid \mathbf{t i m m}}\right]_{w d} \text { ó/ }\end{array}$} & \multirow{2}{*}{$\begin{array}{c}\begin{array}{c}\text { DEP- } \\
\text { ROUND }_{w d}\end{array} \\
* !\end{array}$} & \multirow{2}{*}{\multicolumn{2}{|c|}{$\begin{array}{c:c}\text { DEP- } & \text { DEP- } \\
\text { COR } & \text { ROUND }\end{array}$}} & \multirow[b]{2}{*}{$\begin{array}{c}\text {-FRONT/ } \\
\text { ROUND }\end{array}$} & \multirow[b]{2}{*}{$\begin{array}{c}\text { DEPPATH- } \\
\text { ROUND }\end{array}$} \\
\hline & & & & & \\
\hline a. tơm $\overbrace{w d}^{[-\mathrm{rd}]}$ & $* !$ & & & & * \\
\hline $\begin{array}{cc}-\mathrm{rd}] & {[+\mathrm{rd}]} \\
\text { b. tìm }]_{w d} & \text { ó }\end{array}$ & & $* !$ & & & $*$ \\
\hline c. $\overbrace{\text { timm }]_{w d}}^{[-\mathrm{rd}]}$ é $[+\mathrm{rd}]$ & & $* !$ & & $*$ & \\
\hline 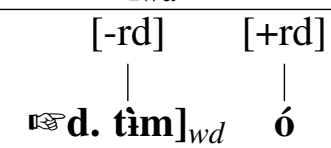 & & & & $*$ & $*$ \\
\hline
\end{tabular}

With the ranking DEP-ROUND ${ }_{w d} \gg$-FRONT/ROUND, the otherwise optimal harmonic output form tòm ó is now ruled out. The failure of (56c) to surface optimal also shows that changing the [+round] specification of the final clitic is not a viable means of avoiding DEPPATH-ROUND violation, as doing so results in the insertion of a coronal feature against the demands of highly ranked DEP-COR.

\subsubsection{OCP and consonant deletion}

Under the analysis that the deletion of a coronal is driven by the Obligatory Contour Principle, this principle, formalised as an OT constraint, becomes the markedness constraint triggering the deletion of one of the adjacent coronal consonants. For deletion to take place, the OCP must outrank the anti-deletion faithfulness constraint: OCP » MAX. However, that is not sufficient to determine the optimal output form. As shown in (57), it does not determine which of the two coronals in sequence is deleted. Deleting either consonant satisfies OCP.

Effects of OCP over MAX: /jíl-jâ/ $\rightarrow$ [jí-jâ] 'house-pl.'

\begin{tabular}{|r||c|c|}
\hline /jíl-jâl & OCP & MAX \\
\hline \hline a. [jíl-jâ]] & $* !$ & \\
\hline b. [jí-jâ]] & & $*$ \\
\hline c. [jíl-âa] & & $*$ \\
\hline
\end{tabular}


In the same way, a positional faithfulness variant of $\left.\mathbf{M A X},(\mathbf{M A X}]_{w d}\right)$, is sufficient to block deletion in words, when it outranks OCP. However, it predicts the wrong surface form, as it is unable to stop an OCP-driven deletion of the suffix-initial coronal.

\begin{tabular}{|c|c|c|c|}
\hline & & & 10 \\
\hline$/ \mathbf{j i ̀ l}]_{w d-\mathbf{j a ́} /}$ & $\mathbf{M A X}]_{w d}$ & OCP & MAX \\
\hline 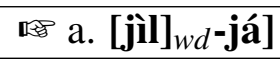 & & $*$ & \\
\hline b. [jì $]_{w d}$-jáa & $* !$ & & * \\
\hline č c. [jìl $]_{w d}$-áa & & & $*$ \\
\hline
\end{tabular}

Indeed, as noted in Section 4.3, the deletion is not confined to one morphological position. In some instances a root-final coronal is deleted, in other cases, the suffix onset coronal is deleted. What is consistent is that, the deletion always targets the lateral consonant / $/$. In (32), root-final / $/$ / is deleted when followed by a suffix with initial $/ \mathrm{j} /$. In (34), suffix-initial $/ \mathrm{l} /$ is deleted when preceded by a root-final $/ \mathrm{n} /$. This motivates a harmony scale in which central coronal sonorants are more harmonic than lateral ones: $[\mathrm{j}, \mathrm{r}, \mathrm{n}] \succ[\mathrm{l}]$. This translates into a faithfulness constraint hierarchy MAX-CENTRAL »MAX-Lateral. ${ }^{7}$

The results in (58) show that the deletion triggered by OCP can not come at the expense of deletion of a central coronal. This provides an indication that MAX-CENTRAL outranks OCP, which in turn ranks above MAX-LATERAL. When the two constraints are integrated into the already existing hierarchy, the new ranking stands as MAX $]_{w d}$, MaX-Central » OCP » MAX-Lateral » MAX. The tableaux in (59) and (60) show how the ranking succeeds in blocking the deletion of non-laterals.

Effects of MAX-CENTRAL » OCP: /jíl-jâa/ $\rightarrow$ [jí-jâ] 'house-pl.'
\begin{tabular}{|r||c|c|c|c|c|}
\hline /jíl-jâ/ & MAX] $]_{w d}$ & $\begin{array}{c}\text { MAX- } \\
\text { CENTRAL }\end{array}$ & OCP & $\begin{array}{c}\text { MAX- } \\
\text { LATERAL }\end{array}$ & MAX \\
\hline \hline a. jíl-jâ & & & $* !$ & & \\
\hline b. jí-jâ & & & & $*$ & $*$ \\
\hline c. jíl-â & & $* !$ & & & $*$ \\
\hline
\end{tabular}

\footnotetext{
${ }^{7} \mathrm{~A}$ reference is made to sonorants here because the deletion takes place only when the lateral is adjacent to another coronal sonorant. An alternative formulation of this harmonic scale in terms of markedness (i.e. *LATERAL » *ENTRAL) could also account for the pattern of lateral deletion. However, see Howe and Pulleyblank (2004) for arguments in favour of formulating harmony scales as faithfulness constraints.
} 
(60)

\begin{tabular}{|c|c|c|c|c|c|}
\hline$/ \mathbf{j i l}]_{w d-\mathbf{j a ́} /}$ & $\mathbf{M A X}]_{w d}$ & $\begin{array}{c}\text { MAX- } \\
\text { CENTRAL }\end{array}$ & OCP & $\begin{array}{c}\text { MAX- } \\
\text { LATERAL }\end{array}$ & MAX \\
\hline a. jill $]_{w d}$-já & & | & $*$ & & \\
\hline b. jì $]_{w d}$-já & $* !$ & & & $*$ & $*$ \\
\hline c. jìl] $]_{w d}$-á & & $* !$ & & & $*$ \\
\hline
\end{tabular}

In terms of underlying segmental sequence, 'house-pl.' and 'sing-perf.' are homophonous: /jil-ja/. The difference between them is the word boundary between the two morphemes in 'sing-perf.' Because there is no word boundary between the morphemes in /jíl-jâ/, the constraint $\mathbf{M A X}]_{w d}$ is not active in (59). This leaves the combined effects of OCP and MAX-CENTRAL to ensure that [1] is deleted. With the word boundary in (60), MAX] $]_{w d}$ and MAX-CENTRAL respectively protect [1] and [j] from deletion by their being ranked higher than OCP. Thus deletion within the word domain is blocked.

In sum, this section demonstrates that by incorporating sensitivity to the word domain into constraints, two of the observations made in this paper (the asymmetrical application of phonological processes and the clear distinction between the morphological units affected and those not affected) receive a straightforward formal phonological analysis. Therein lies the relevance of the positional faithfulness analysis.

\section{Summary and Conclusions}

This paper has sought to demonstrate how different phonological processes can be used to define the phonological word in Dagbani. It argues that the application of these phonological processes is conditioned by the morphological domains in which potential target sounds occur. In some of these domains, processes that lead to deletion, neutralisation or loss of contrast apply without restrictions. In other domains, such processes are blocked when triggered across their boundaries. This has the effect of preserving segmental contrast or the featural integrity of segments. It argues that the asymmetry between these domains reflects their positional strength or privilege. The strong or privileged positions impose restrictions on the application of phonological rules; the weak positions have less restrictions. A formal account of the asymmetry is illustrated using positional faithfulness approach to analysis of nasal place assimilation, rounding harmony and lateral deletion.

The overall goal has been to demonstrate that the processes discussed here fall within the areas which, in Dixon and Aikhenvald's (2002) definition, the defining properties of a phonological word surface. The conclusion for Dagbani is that, when any 
of the processes or rules triggered by an element within a domain A affects a segment located in a domain B, then domain B does not constitute a phonological word. A full phonological word is one that permits these processes only when they are triggered by elements within the same domain. In other words, when these phonological processes take place, the trigger and targets must be part of the same phonological word. When segments within a morphological domain fail to undergo a process, the likelihood is that the trigger of that process is not part of the same phonological word as the potential targets that fail to undergo the process.

In addition to providing further details about aspects of Dagbani morphology discussed in past studies, this paper is the first description of some of the phonological processes discussed, including lateral deletion and height harmony. In this respect, the paper has made a significant contribution to the understanding of Dagbani morphophonology. The paper has also contextualised these morphophonological processes within cross-linguistic observations, used them to explain phonological principles such as the Obligatory Contour Principle and underspecification, and subjected them to theoretical analyses such as Feature Geometry and Optimality Theory. What is more, it has shown that a coherent account of some of these processes can not be achieved without reference to the morphological domains within which the target segments occur. For instance, without reference to the morphological differences between nouns and verbs, it will be difficult to explain why /jíl-jâ/ 'house-pl.' surfaces as [jí-jâ], with lateral deletion, while /jìl-já/ 'sing-perf.' surfaces as [jìl-já], without deletion.

The conclusions drawn in the discussions and analyses need to be understood within the context of the variations observed with respect to the application of the phonological processes discussed here. Saying that affixes, bound roots and clitics do not constitute phonological words by themselves does not imply that each of the phonological processes discussed here will affect any of these constituents when triggered across its boundary. Rather, the conclusion is that, the effect of these processes on any of these constituents is sufficient as a diagnostic of its sub-wordhood as long as an asymmetrical pattern of their lack of effect on free roots, complex words and compounds can be established. For instance, vowel height harmony is shown to affect some nominal forms, changing their height specification. The argument is that, the height neutralisation takes place because the root vowel is underlyingly unspecified for some vocalic features. The key point here is that, underspecification and its resulting effect of height neutralisation are associated with bound roots, not full words. In a full phonological word, all segments must be fully specified. However, not all bound roots show these phonological traits. A root does not have to be underlyingly unspecified for features to be included in the category of bound root. In other words, non-uniformity in rule application to segments in various morphological units is expected. 
Hudu: The Phonological Word in Dagbani

\section{References}

Alderete, John. D., 2003. Structural disparities in Navajo word domains: A case for lexcat-faithfulness. The Linguistic Review 20: 111-157.

Archangeli, Diana, and Douglas Pulleyblank, 1994. Grounded phonology. Cambridge MA: MIT Press.

Baković, Eric, 2000. Harmony, dominance and control. PhD Dissertation, Rutgers University.

Beckman, Jill, and Catherine Ringen, 2004. Contrast and redundancy in OT. In Proceedings of the 23rd West Coast Conference on Formal Linguistics, ed. Vineeta Chand, Ann Kellerher, Angelo J. Rodríguez, and Benjamin Schmeiser: 101-114. Somerville, MA: Cascadilla Press.

Beckman, Jill, 1998. Positional faithfulness. PhD Dissertation, University of Massachusetts Amherst.

Beckman, Jill, 1997. Positional faithfulness, positional neutralization and Shona height harmony. Phonology 14: 1-46.

Benzing, Brigitta, 1971. Neues Material zur Morphologie der Nominalklassen in Dagbani. Hamburger Beiträge zur Afrika-Kunde, Bd. 14, Afrikanische Sprachenund Kulturen, Ein Querschnitt. 66-78.

Blench, Roger, 2004. Dagbani-English dictionary. With contributions from Harold Blair Tamakloe, Harold Lehmann, Lee Shin Chul, André Wilson, Maurice Pageault, Knut Olawsky and Tony Naden. Tamale.

Casali, Roderic F., 1997. Vowel elision in hiatus context: Which vowel goes? Language 73: 493-533.

Casali, Roderic F., 1996. Resolving hiatus. PhD Dissertation, University of California Los Angeles.

Dakubu, Mary Esther Kropp, 1997. Oti-Volta vowel harmony and Dagbani. Gur Papers 2: 81-88. 
Dixon, Robert Malcolm Ward, and Alexandra Y. Aikhenvald, 2002. Word: a typological framework. In Word: a cross-linguistic typology, ed. Robert Malcolm Ward Dixon and Alexandra Y. Aikhenvald, chapter 1: 1-41. Cambridge: Cambridge University Press.

Goldsmith, John, 1990. Autosegmental and metrical phonology. Oxford: Blackwell.

Harris, James W., 1969. Spanish phonology. Cambridge: MIT Press.

House, A S., 1957. Analogue studies of nasal consonants. Journal of Speech and Hearing Disorders 22: 190-204.

Howe, Darin, and Douglas Pulleyblank, 2004. Harmonic scales as faithfulness. Canadian Journal of Linguistics 49: 1-49.

Hudu, Fusheini, 2014. [ATR] feature involves a distinct tongue root articulation: Evidence from ultrasound imaging. Lingua 143: 36-51.

Hudu, Fusheini, 2013. Dagbani tongue-root harmony: triggers, targets and blockers. Journal of African Languages and Linguistics 34: 47-73.

Hudu, Fusheini, 2012. Dagbani focus particles: a descriptive study. Journal of West African Languages 39: 97-129.

Hudu, Fusheini, 2010. Dagbani tongue-root harmony: a formal account with ultrasound investigation. PhD Dissertation, University of British Columbia.

Hudu, Fusheini, 2005. Number marking in Dagbani. Msc. thesis, University of Alberta.

Itô, Junko, and Armin Mester, 1993. Licensed segments and safe paths. Canadian Journal of Linguistics 38: 197-213.

Itô, Junko, Armin Mester, and Jaye Padgett, 1995. Licensing and underspecification in Optimality Theory. Linguistic Inquiry 26: 571-613.

Kim, Eun-Sook, 2003. Theoretical issues in Nuu-cha-nulth phonology and morphology. PhD Dissertation, University of British Columbia.

Kim, Eun-Sook, and Douglas Pulleyblank, 2009. Glottalization and lenition in $\mathrm{Nu}$ cha-nulth. Linguistic Inquiry 40: 567-617. 
Hudu: The Phonological Word in Dagbani

Kirchner, Robert, 1993. Turkish vowel harmony and disharmony: an Optimality Theoretic account. Presented at Rutgers Optimality Workshop I.

Ladefoged, Peter, 1968. A phonetic study of West African languages: An auditoryinstrumental survey. Cambridge: Cambridge University Press, 2nd edition.

Leben, William, 1973. Suprasegmental phonology. PhD Dissertation, Massachusetts Institute of Technology.

Letterman, Rebecca Susan, 1997. The effects of word-internal prosody in Sinhala: A constraint-based analysis. PhD Dissertation, Cornell University.

Malécot, A., 1960. Vowel nasality as a distinctive feature in American English. Language 26: 222 - 229.

Malécot, A., 1956. Acoustic cues for nasal consonants: an experimental study involving tape-splicing technique. Language 32: 274-284.

McCarthy, John J., 2009. Harmony in Harmonic Serialism. University of Massachusetts Amherst.

McCarthy, John J., 2004. Headed spans and autosegmental spreading. University of Massachusetts, Amherst.

McCarthy, John J., 1988. Feature geometry and dependency: a review. Phonetica 43: 84-108.

McCarthy, John J., and Alan Prince, 1995. Faithfulness and reduplicative identity. In University of Massachusetts Occasional Papers in Linguistics, ed. Jill Beckman, Laura Walsh Dickey, and Suzanne Urbanczyk, volume 8: 294-384. Amherst: University of Massachusetts.

McCarthy, John J., and Alan Prince, 1990. Prosodic morphology and templatic morphology. In Perspectives in Arabic linguistics II, ed. Mushira Eid and John J. McCarthy, volume 72 of Current issues in linguistic theory: 1-54. Amsterdam: John Benjamins.

Miehe, Gudrun, 2012. Dagbani. In Noun class systems in Gur languages Vol. II, ed. Gudrun Miehe, Brigitte Reineke, and Kerstin Winkelmann: 330-349. Köln: Rüdiger Köppe Verlag. 
Miehe, Gudrun, Brigitte Reineke, and Kerstin Winkelmann, ed., 2012. Noun class systems in Gur languages Vol. II . Köln: Rüdiger Köppe Verlag.

Miehe, Gudrun, and Kerstin Winkelmann, ed., 2007. Noun class systems in Gur languages. Köln: Rüdiger Köppe Verlag.

Myers, Scott, 1997. OCP effects in Optimality Theory. Natural Language and Linguistic Theory 15: 847-892.

Naden, Tony, 1988. The Gur Languages. In The languages of Ghana, ed. Mary Esther Kropp Dakubu: 12-49. London: Kegan Paul.

Ohala, John J, 1975. Phonetic explanations for nasal sound patterns. In Nasalfest: Papers from Symposium on Nasals and Nasalisation, ed. John J. Ohala C. A. Feguson, L. M. Hyman: 289-316. Stanford: Stanford University.

Olawsky, Knut J., 2002. What is a word in Dagbani? In Word: a cross-linguistic typology, ed. Robert Malcolm Ward Dixon and Alexandra Y Aikhenvald: 205226. Cambridge: Cambridge Univiversity Press.

Olawsky, Knut J., 1999. Aspects of Dagbani grammar: with special emphasis on phonology and morphology. LINCOM Europa.

Padgett, Jaye, 2002. Feature classes in phonology. Language 78: 81-110.

Padgett, Jaye, 1995. Partial class behaviour and nasal place assimilation. In Proceedings of the 1995 Southern Workshop on Optimality Theory, ed. Keiichiro Suzuki and Dirk Elzinga: 145-183. Tuscon, Arizona.

Padgett, Jaye, 1994. Stricture and nasal place assimilation. Natural Language and Linguistic Theory 12: 465-513.

Prince, Alan, and P. Smolensky, 1993/2004. Optimality Theory: constraint interaction in generative grammar. Malden, MA: Blackwell Publishers.

Pulleyblank, Douglas, 1997. Optimality Theory and features. In Optimality Theory an overview, ed. Diana Archangeli and D. Terence Langendoen: 59-101. Malden, Massachusetts: Blackwell Publishers.

Pulleyblank, Douglas, 1996. Neutral vowels in Optimality Theory: a comparison of Yoruba and Wolof. Canadian Journal of Linguistics 41: 295-347. 
Hudu: The Phonological Word in Dagbani

Sacia, C. F., and C. J. Beck, 1926. The power of fundamental speech sounds. Bell System Technical Journal 5: 393-403.

Smith, Jennifer L., 2001. Lexical category and phonological contrast. In PETL 6: Proceedings of the Workshop on the Lexicon in Phonetics and Phonology, ed. Robert Kirchner and Joe Pater: 61-72.

Troubetzkoy, Nikolai Sergeevich, 1939. Grundzüge der Phonologie. Sprachwissenschaft. Ein Reader 2.

Walker, Rachel, 1998. Nasalization, neutral segments, and opacity effects. PhD Dissertation, University of California Santa Cruz.

Wilson, Colin, 2003. Analyzing unbounded spreading with constraints: marks, targets, and derivations. Los Angeles: University of California Los Angeles.

Wilson, W. A. A., 1972. An introductory course on Dagbani. Ghana Institute of Linguistic, Literacy and Bible Translation.

Zoll, Cheryl, 2004. Positional asymmetries and licensing. In Optimality Theory in phonology, a reader, ed. John J. McCarthy: 365-378. Oxford: Blackwell.

Zoll, Cheryl, 1997. Conflicting directionality. Phonology 14: 263-286. 